Sharif University of Technology
Scientia Iranica
SCIENTIA
I RAN I CA
http://scientiairanica.sharif.edu

\title{
Applying materials waste quantification to cement waste reduction in residential buildings of Tehran: A case study
}

\author{
A. Mahpour*, A. Alvanchi, and M.M. Mortaheb \\ Construction Engineering and Management Group, Department of Civil Engineering, Sharif University of Technology, Azadi \\ Avenue, Tehran, Iran.
}

Received 22 August 2016; received in revised form 4 September 2017; accepted 18 November 2017

\author{
KEYWORDS \\ Building materials \\ waste; \\ Quantification; \\ Construction waste \\ reduction; \\ Cement; \\ Tehran residential \\ buildings; \\ Iran.
}

\begin{abstract}
The purpose of this research was twofold; first, it focused on developing quantitative wastage models for rebar, concrete, brick, and cement, as major traditional bulk building materials, used in Tehran residential buildings. The primary results indicated that multiple linear regression was an apt tool to model the effects of the studied variables on materials wastage. In every developed wastage model, subtractive or accumulative effect of each studied variable was recognized by its coefficient value and sign. The developed models resulted in adjusted $R^{2}$ values of $0.907,0.875,0.920$, and 0.790 , respectively, for rebar, cement, brick, and concrete waste. Cement, with average wastage of $8.57 \%$ by weight, was identified as the most wasted material verified by the case study. As the second objective of the study, the previously developed models as well as opinions of the project management experts were combined to propose a cement waste reduction guideline for traditional building construction, which is common in Tehran, Iran. With this purpose in mind, in the initial phase of the project, choosing lump-sum contract instead of cost-plus contract was considered. Moreover, a financial incentive reward scheme, with its economic viability and environment friendliness, was tested, which yielded positive results and hence, was proposed for the construction phase. Applicability of the proposed scheme was verified through a case study.

(C) 2019 Sharif University of Technology. All rights reserved.
\end{abstract}

\section{Introduction}

Construction Waste (CW) as a crucial global concern is an important part of solid waste; it is a direct by-product of construction industry that unfavorably affects the environment [1-5]. Construction and Demolition Waste (C\&DW) produces about one third of

\footnotetext{
*. Corresponding author. Fax: +982166013201 E-mail addresses: mahpour_amirreza@alum.sharif.edu (A. Mahpour); alvanchi@sharif.edu (A. Alvanchi); mortaheb@sharif.edu (M.M. Mortaheb)
}

total landfill wastes [2] and has caused pressure on landfill sites [6]. Furthermore, construction industry is responsible for $30 \%$ of the global carbon emissions. It is expected that its share will be doubled during the next 20 years [7], which suggests $C W$ as a culprit in global warming. Asthma attacks, premature deaths, and reduction in lung functionality in children are stemmed from CW Generation (CWG) as well as its accumulation in the ozone layer [8]. CWG quantification is a primary tool for serving other construction waste management policies, i.e., legislation or incentive proposals [9,10]. It fulfills data scarcity; alleviates determining, controlling, and managing CWG; facilitates CW management; and can be used to control CW 
environmental consequences [3,11], i.e., climate change, acidification, summer smog, and nitrification [12]. It provides contractors who are supposed to generate less CW with insight [13].

By a review of the literature, it is discernable that Kern et al. [9] conducted a Multiple Linear Regression (MLR) based study and evolved CWG model in highrise buildings in Brazil. They deemed production system and design process salient influential parameters on CWG estimation. Sáez et al. [14] investigated project Floor Area (FA) and number of dwellings in several newly built residential building projects and proposed a quantification model in terms of volume and weight for CWG in the Mediterranean buildings. Ding and Xiao [15] quantified C\&DW generation in buildings in Shanghai, China, by scrutinizing the outcomes of structure design and affiliated structure codes in several decades on CWG fluctuations. Based on mass balance principle for construction, $\mathrm{Li}$ et al. [16] generated a model for quantifying CWG per gross FA, which was applied to the construction of a residential building in Shenzhen, China. Won et al. [17] categorized design errors based on their causes and likelihood of detection in order to quantify the construction waste prevented. They studied two cases in South Korea with 381 and 136 design errors detected. By adopting BIM (Building Information Modeling)-based design validation, they could prevent $4.3-15.2 \%$ of construction waste. Ghosh et al. [18] quantified C\&D waste generated in Kolkata, India, using building-specific and region-specific waste generation rates. The research was done between May 2015 and August 2015 on 5 ongoing demolition and renovation projects and ended up by optimizing the value of revenue that could be recovered by recycling C\&D waste [18].

The most important weakness of these models is that they are true for specific cases and there is no single model for estimating waste generation that is applicable to each given situation [18]. Additionally, waste generation does not necessarily comply with the existing regressions and some developed models have significant error terms. To lessen the error terms, we need to increase the number of studied projects, which seems impractical due to time-consuming and difficult nature of gathering data. As well as being true for a limited number of buildings, they are generally applicable to a limited total amount of construction or demolition waste. They also do not consider contract type and locality, which seem to be important factors in construction waste generation. The present paper fills these gaps by developing quantitative models for each material and including contract type and locality in modeling process by studying 32 construction projects, which are significantly more than the numbers of studied projects in the previous studies (18 at most).

CW quantification provides useful models, which can be used to reduce waste. Waste reduction has been identified as a part of the 3R approach (reduction, reuse, and recycle) in order to make societies more sustainable [1]. In some Asian countries, several approaches have been taken to the development of 3R performance indicators [19]; all the same, no significant effort has been undertaken in Iran so far to develop approaches based on $3 \mathrm{R}$ policy to minimizing/managing CW:

- Although municipalities and the government highlight the importance of waste management, there is no practical action;

- There is no unique regulation of $\mathrm{CW}$ reduction, reuse, or recycling and the existing regulations merely aim at collection and disposal of solid waste;

- People and dignitaries are unaware of damages of CW.

Even though in recent years, municipalities have tried to lay down rules and legislations to manage $\mathrm{CW}$, it is not clear when these actions will come into practice [20]. When there is no comprehensive plan to manage all wastes, the municipality can start the task of waste reduction with the most dominant type of waste. With this purpose in mind, managers can think about cement waste reduction. This is due to the fact that cement is one of the highly consumed Building Materials (BMs). Iran ranked fifth among cement producing countries in the world from 2003 to 2012. Annual cement production in Iran was 30.5, $32.6,40.0,56.3,61.0$, and 65.0 million tons in 2003, 2005, 2007, 2009, 2011, and 2012, respectively [21]. Table 1 represents average quantities of environmental

Table 1. The average quantities of some environmental indicators for 5 cement companies in Iran [22].

\begin{tabular}{lccl}
\hline \multicolumn{1}{c}{ Indicator } & & Average & \multicolumn{1}{c}{ Unit } \\
\hline Raw materials consumption & & 1.64 & $\mathrm{t} / \mathrm{t}$ cement produced \\
Electrical energy consumption & & 99.79 & $\mathrm{kWh} / \mathrm{t}$ cement produced \\
Heat energy consumption & & 827.19 & $\mathrm{kcal} / \mathrm{kg}$ cement produced \\
Air pollutants emission & $\mathrm{CO}_{2}$ & 933.80 & $\mathrm{~kg} / \mathrm{t}$ cement produced \\
& $\mathrm{NO}_{x}$ & 2.47 & $\mathrm{~kg} / \mathrm{t}$ cement produced \\
& $\mathrm{SO}_{2}$ & 522.40 & $\mathrm{~kg} / \mathrm{t}$ cement produced \\
& $\mathrm{SPM}$ & 99.60 & $\mathrm{~kg} / \mathrm{t}$ cement produced \\
\hline
\end{tabular}


indicators of greenhouse gases production for 5 cement companies in Iran [22]. Currently, greenhouse gases emissions control is regarded as a highly outstanding environmental subject [23]. Researchers have proposed solutions to reducing production, usage, and wastage of BMs including cement. Tam and Tam [24] implemented a Financial Incentive (FI) reward program. Following a ladder approach, the reward was augmented as the wastes decreased. This scheme decreased CWG to $23 \%$ in Hong Kong. To reduce $\mathrm{CO}_{2}$ emission, Oh et al. [21] proposed using demolished inorganic BMs instead of limestone in cement production. Ostad-Ahmad-Ghorabi and Attari [22] prioritized 15 indicators using Technique for Order of Preference by Similarity to Ideal Solution (TOPSIS, a multicriteria decision making model that could be utilized for the purpose of prioritizing the indicators based on the quantities and relative importance achieved) and developed strategies to advance environmental evaluation of cement production industry in Iran. Chen et al. [25] developed a series of suggestions including replacing limestone with wastes to reduce detrimental effects of cement production.

In Tehran, CW constitutes approximately 10$30 \%$ of C\&DW [2]. In 2009, in Tehran, 46,655 $\mathrm{m}^{3}$ /day (equivalent to: 14.70 million tons/year, 1300$1610 \mathrm{~kg} / \mathrm{m}^{2}$ built, $1694.35 \mathrm{~kg} /$ person/year, and about five times the household waste) C\&DW was generated. This huge quantity is postulated to be mainly due to short lifetime of buildings, natural disasters, substandard safety codes, growing demands for modern construction projects, and poor maintenance. Other factors such as old construction methods, i.e., brickbased, dominancy of traditional demolition methods, low rate of reusing and recycling, and landfilling and illegal dumping could add up to such big amounts of C\&DW. On the other hand, growing population is pushing housing demands that leads to more BMs usage and wastage [26]. In addition, Mehr Public Housing Project, which started 10 years ago, includes construction of about 350,000 low-cost condos and consumes tremendous amounts of $\mathrm{CMs}$ and generates huge amounts of CW all over Iran, and Tehran is not an exception.

Detrimental environmental effects of generating high amounts of CW/C\&DW have obliged governments to make plans of $\mathrm{CW}$ management since several decades ago. The results are various regulations that have been devised and implemented all over the world. For instance, in Hong Kong, the following regulations control CW Generation (CWG): waste disposal ordinance, green manager scheme, waste reduction framework plan, practical note on the use of recycled aggregate, commissioning a pilot recycling plant to supply recycled aggregate, circulars of waste management, and public landfill levy scheme [24]. Besides these limiting regulations, incentive-based techniques and combined systems of bonus and penalty are posited to help in attaining more efficacy $[24,25]$. The required incentive can be provided by means of financial aid, upgrading certificates, etc.

The aim of the present study is to propose a construction waste reduction model valid in Tehran context. The following objectives are set for this study: determining influential parameters on materials wastage, quantifying the studied materials wastage, investigating applicability of FI reward programs to reducing materials wastage, and proposing a viable and environment friendly FI reward program in case its applicability is proven.

\section{Theory and methodology}

So far, possible effects of locality on CW generation have not been investigated by scholars, although some researchers are in favor of potential influence of the former on the latter. To evaluate the effect of locality on $\mathrm{CW}$ generation in practice, the authors narrowed down their research on residential buildings to Tehran, Iran. As a matter of fact, these buildings were a case study to initiate and conduct the investigation. The first part of the study focused on developing a building-level model to quantify rebar, concrete, brick, and cement wastages. These four materials are highly consumed in traditional residential projects. The average wastages (wasted material quantity over purchased material quantity) of rebar, concrete, brick, and cement in Tehran, Iran, are $1.358 \%, 3.793 \%, 6.049 \%$, and $8.403 \%$, respectively [2]. Other unstudied materials were either cheaper or less commonly utilized than the studied BMs in traditional construction projects. Variables of the study were derived from the available reviewed literature. The required data were obtained through the first questionnaire survey. After data treatment, MLR by IBM SPSS was identified as a proper tool for data analysis. Various combinations of the variables were evaluated. Finally, the models satisfying the acceptance criteria were derived from the most recent and relevant papers and statistical references, which are reported in this paper. The first part suggested that cement was highly wasted in the studied projects. Therefore, in the second part, using the results of the first part of the study and insights of project management experts gathered through the second questionnaire survey, a Cement Waste Reduction (CWR) guideline is suggested. Figure 1 illustrates the procedure of the present research.

\subsection{The first questionnaire survey and sample characteristics}

The required data for both parts were collected through the first questionnaire survey for 32 residential build- 


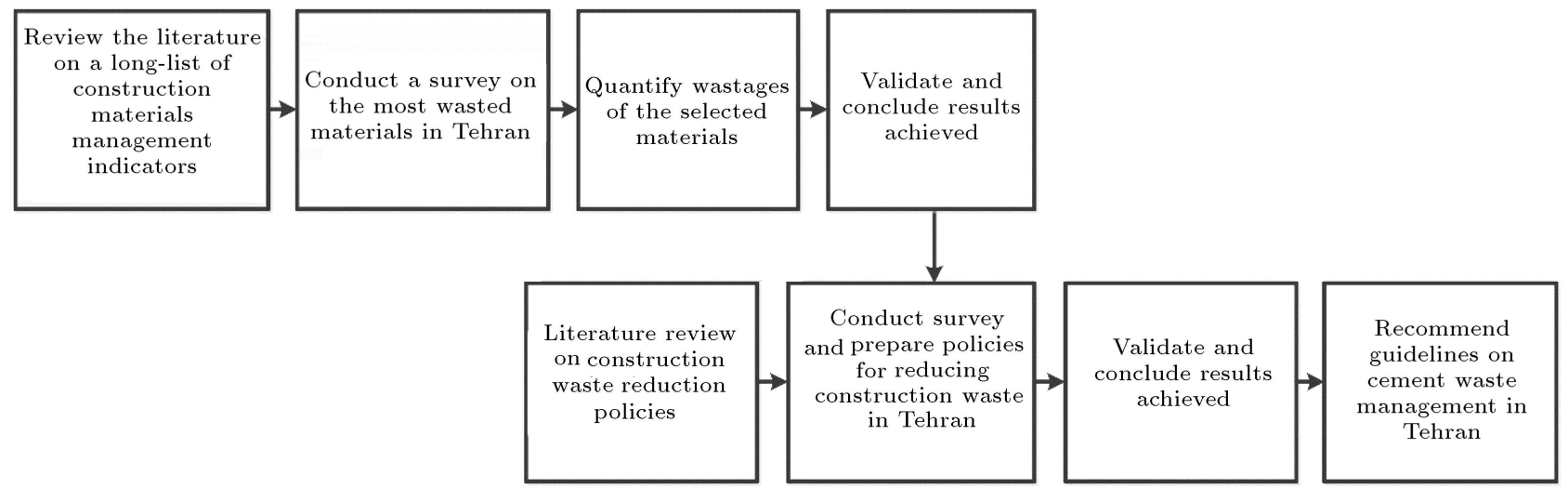

Figure 1. The research procedure diagram.

ings being built in Tehran, Iran. The respondents were contractors of the projects, who were supposed to declare/estimate the amounts of purchased and wasted materials in order to obtain the materials wastage percentage by weight.

\subsubsection{Research variables}

BMs Waste (BMW) is complicated enough to quantify, as it is a function of a set of variables [9,27]. In this paper, the dependent variable consists of the aforementioned four BMs wastage during construction in terms of weight percent. Parameter $Y_{\text {Site }}^{\text {Material }}$ generally represents these variables, so BMW weight percentages are presented as $Y_{\text {Site }}^{\text {Rebar }}, Y_{\text {Site }}^{\text {Concrete }}, Y_{\text {Site }}^{\text {Brick }}$, and $Y_{\text {Site }}^{\text {Cement }}$. The studied independent variables are the following:

- Contract type: There are a variety of contract types in construction industry, e.g., unit price, lumpsum, cost-plus, etc., of which content rules and regulations affect the way the contractor attempts to superintend CWG [28]. The focus of this study is on lump-sum and cost-plus contracts since they are widely used in residential building projects in Tehran. The contract type is a qualitative variable and needs to be in a numerical form in order to be analyzed [9]. Parameter $X_{1}$ presents this variable and equals 0 and 1 for cost-plus and lump-sum contracts, respectively.

- FA: FA affects the design of the building and BMs waste, because the more the FA, the more will be the purchased materials [29]. To make the coefficient of this variable in the same order of that of the other variables, a new parameter, $A$, which is defined as one hundredth of FA is used to develop the models:

$$
A=\frac{F A\left(\mathrm{~m}^{2}\right)}{100} \text {. }
$$

For the studied buildings:

$$
50 \mathrm{~m}^{2} \leq F A \leq 235 \mathrm{~m}^{2},
$$

$$
0.50 \leq A \leq 2.35
$$

- Locality: Differences are climate conditions, training level of the local labor, and land prices. Such factors make locality an efficacious parameter in BMW. In this study, 7 different locations in Tehran were selected and 32 residential buildings were studied. These locations were selected in such a manner to cover the whole land price range in Tehran. Furthermore, each studied building was typical in order to represent a variety of buildings in the same location. The authors believe that the studied set of buildings is a good representative sample of residential buildings in Tehran. Similar to contract type variable, locality qualitative variable must be in numerical form [9] to be analyzed. For every residential building, the amount of the corresponding locality parameter is set to 1 and the rest of locality parameters are set to 0 . Table 2 shows the characteristics of the studied locations.

- Number of stories: Building height restrictions are surmised to control the way pollutant dispersion and pedestrian ventilation are affected by building height [30]. A building's number of stories $(S)$ is an

Table 2. Locations, their notations, and number of buildings in each location.

\begin{tabular}{ccc}
\hline $\begin{array}{c}\text { Location } \\
\text { (Tehran, Iran) }\end{array}$ & Notation & $\begin{array}{c}\text { Number of buildings } \\
\text { in location }\end{array}$ \\
\hline Imam Hosein & $X_{2}$ & 5 \\
Saadat-Abad & $X_{3}$ & 7 \\
Shohada & $X_{4}$ & 4 \\
Shahran & $X_{5}$ & 4 \\
Resalat & $X_{6}$ & 4 \\
Tehran no. & $X_{7}$ & 4 \\
Sepah & $X_{8}$ & 4 \\
Total & & 32 \\
\hline
\end{tabular}


indicator of its height and supposed to be one of the CWG quantification independent variables $[9,11]$. For the studied residential buildings:

$$
S \in\{4,5,6,7\}
$$

These independent variables are used in the first part of the study. In addition to these parameters, another parameter is to be defined to notate financial incentive and to conduct the second part of the study.

- FI: In Iran, there is no contrivance to control CWG. FIs are regarded as effective methods for compelling contractors to reduce the $\mathrm{CW}$ they generate as discussed in Section 1. Therefore, the authors decided to evaluate an FI-based program for controlling CWG in Tehran. This parameter is suggested to be calculated according to Eq. (5).

Moreover, the authors conducted the second questionnaire survey in Likert scale to evaluate dominance of FI over other CWG reduction methods, i.e., finingbased methods. A long list of indicators was first extracted from reviewed research efforts in the literature $[21,25,31,32]$. The final short list of indicators was then deduced from a set of meetings held with experts. The final questionnaire subsumed 17 indicators. Indicators no. 1 to 4,9 to 11 , and 14 to 17 were suggested by the experts with more than 20 years of experience in construction industry prior to designing the questionnaire. Other items were deduced from the following reviewed papers:

- Items no. 5, 7, and 12 from the paper of Tam and Tam, 2008 [24];

- Items no. 6, 8, and 13 from the paper of Chen et al., 2002 [25].

The indicators covered the preferences of construction industry experts (1- dominance of ethics over incentives, 2- dominance of incentives over penalizing, 3- effectiveness of incentives in all contracts, 4- influence of promoting ethical beliefs about waste reduction), legislative (5- imperativeness of assigning a budget to pay incentives, 6- effect of incentives on reduction in materials production, 7- relation of incentives with revenue of contractors, 8- relation of required budget with revenue of municipalities from rehabilitation projects), managerial (9- imperativeness of determining maximum allowed wastage of materials, 10- possibility of circumventing the rules requiring control, 11- dominance of incentives due to lower need for controlling mechanisms, 12- potential positive effects of trainings on waste reduction, 13- potential positive effects of ladder approach to designing incentives on waste reduction), and sustainable development related aspects of proposal (14- relation of the success of incentive plans with reduction in materials demand, 15- alignment of incentive plans with national benefits, 16- alignment of incentive plans with sustainable development, 17- incentives resulting in promotion of utilizing biodegradable materials by contractors).

Fifty-four experts took part in this survey and were supposed to assign a number from 1 (completely disagree) to 5 (completely agree) to each indicator. Table 3 shows characteristics of the respondents. To check the internal and overall consistency of indicators, Cronbach's alpha was calculated. Since $\alpha=0.776>$ 0.700 , favorable consistency was approved. Thus, the proposal was preferred to fining policies by respondents. Other results of the second questionnaire survey are the following:

- There is theoretical relationship between FI and materials waste reduction in Tehran residential building projects;

- In order to be applicable, the proposed FI programs must be feasible both economically and environmentally;

- Construction industry experts believe that FI reward programs are prioritized not only over fining policies but also over other materials waste reduction policies, e.g., legislation, regulating codes, increasing existing fines, etc., because lower supervision and control is required in implementing reward programs than in other mentioned methods;

- FI rewards inspire stakeholders of construction projects intuitively and trigger professional ethics more efficiently than other methods do;

- Even in projects employed by cost-plus contracts in which the contractor has the least apathy toward materials waste reduction, FI plans can convince them to reduce wasted materials to the possible extent;

- Demand for construction materials production and consumption will be reduced provided that FI reward programs are implemented in a big city with many construction projects like Tehran;

- FI reward programs are toward sustainable development, because in case of implementing these programs, less materials and resources will be wasted and more will be saved for future generations.

The authors proposed an initial amount of FI equal to demolition waste generation charge (Eq. (5)), hoping that it would persuade contractors more than fining policies. Since in case of defining a new taxing policy, instead of enforcing taxes on them, the contractors will be rewarded if the mentioned waste generation is either avoided or reduced:

$$
D C=0.2 K . P . F A,
$$


Table 3. Characteristics of respondents.

\begin{tabular}{|c|c|c|c|c|c|}
\hline \multirow[t]{2}{*}{ Property } & & \multirow{2}{*}{$\begin{array}{l}\text { Number of } \\
\text { respondents }\end{array}$} & \multirow{2}{*}{$\begin{array}{c}\text { Relative } \\
\text { percentage }\end{array}$} & \multicolumn{2}{|c|}{ Sum } \\
\hline & & & & Total & Percent \\
\hline \multirow[t]{2}{*}{ Gender } & Male & 39 & 72.22 & 54 & 100 \\
\hline & Female & 15 & 27.78 & & \\
\hline \multirow[t]{5}{*}{ Age } & $0-25$ & 2 & 3.70 & 54 & 100 \\
\hline & $26-35$ & 32 & 59.26 & & \\
\hline & $36-45$ & 11 & 20.37 & & \\
\hline & $46-55$ & 6 & 11.11 & & \\
\hline & $\geq 56$ & 3 & 5.56 & & \\
\hline \multirow[t]{6}{*}{ Work experience (years) } & $0-5$ & 17 & 31.48 & 54 & 100 \\
\hline & $6-10$ & 16 & 29.63 & & \\
\hline & $11-15$ & 8 & 14.81 & & \\
\hline & $16-20$ & 5 & 9.26 & & \\
\hline & $21-25$ & 3 & 5.56 & & \\
\hline & $\geq 26$ & 5 & 9.26 & & \\
\hline \multirow[t]{4}{*}{ Field of study } & Civil and environmental engineering & 42 & 77.78 & 54 & 100 \\
\hline & Industrial engineering & 5 & 9.26 & & \\
\hline & Architecture & 6 & 11.11 & & \\
\hline & Surveying and geospatial engineering & 1 & 1.85 & & \\
\hline \multirow[t]{4}{*}{ Degree } & Associate's & 1 & 1.85 & 54 & 100 \\
\hline & $\mathrm{BSc}$ & 19 & 35.19 & & \\
\hline & MSc & 29 & 53.70 & & \\
\hline & $\mathrm{PhD}$ & 5 & 9.26 & & \\
\hline
\end{tabular}

Table 4. Suggested quantities for the parameter $K$ [33].

\begin{tabular}{cccccccccc}
\hline FA $\left(\mathbf{m}^{2}\right)$ & $0-60$ & $61-100$ & $101-150$ & $151-200$ & $201-300$ & $301-400$ & $401-500$ & $501-600$ & More than 600 \\
\hline $\boldsymbol{K}$ & 0.5 & 0.6 & 0.7 & 0.8 & 0.9 & 1.0 & 1.1 & 1.2 & 1.5 \\
\hline
\end{tabular}

where $D C$ is demolition charge for a building in terms of USD ( $\$$ represents USD in all parts of the paper), $K$ is correction coefficient presented in Table 4, FA is floor area in terms of $\mathrm{m}^{2}$ [33], and $P$ is "Last Trading Value" according to building location obtained from Table 5 in terms of $\$[34]$.

All collected data in the first questionnaire survey as well as FI parameters are shown in Tables 5 and 6 .

\subsection{Statistical data treatment}

Data treatment is of paramount importance for checking data set normality and choosing the proper data analysis method.

\subsubsection{Dependent variable statistical analysis}

MLR is feasible when data distribution is normal. Central limit theorem implies that distribution of the sample mean, the variables of which have normal distribution, is normal [9]. When sample size is greater than 25 (the sample size is 32 in this paper), chisquare statistical test can be used to check dependent variable normality and the data set is normal if Eq. (6) is satisfied $[35,36]$. The test procedure begins with arranging $n$ observations into a set of $k$ classes, and goodness of fit is accepted when [35]:

$$
X_{0}^{2}<X_{\alpha, k-s-1}^{2}
$$


Table 5. Collected data (independent variables) and calculated FI for each studied residential building.

\begin{tabular}{|c|c|c|c|c|c|c|c|}
\hline \multicolumn{5}{|c|}{ Collected data } & \multicolumn{3}{|c|}{ Calculated FI } \\
\hline Contract type & Building no. & FA $\left(\mathrm{m}^{2}\right)$ & Number of stories & Location & $K$ & $\boldsymbol{P}(\$)^{*}$ & FI $(\mathrm{k} \$)$ \\
\hline \multirow{17}{*}{$\begin{array}{l}\Xi \\
\Xi \\
0 \\
1 \\
\stackrel{0}{\Xi} \\
\Xi \\
\exists\end{array}$} & 1 & 107 & 5 & $X_{2}$ & 0.7 & 13.619 & 0.204 \\
\hline & 2 & 132 & 5 & $X_{2}$ & 0.7 & 13.578 & 0.251 \\
\hline & 3 & 195 & 4 & $X_{3}$ & 0.8 & 3.898 & 0.122 \\
\hline & 4 & 235 & 7 & $X_{3}$ & 0.9 & 0.445 & 0.019 \\
\hline & 7 & 60 & 4 & $X_{2}$ & 0.6 & 47.904 & 0.345 \\
\hline & 9 & 140 & 5 & $X_{4}$ & 0.7 & 1.622 & 0.032 \\
\hline & 10 & 105 & 5 & $X_{4}$ & 0.7 & 11.159 & 0.164 \\
\hline & 11 & 210 & 5 & $X_{6}$ & 0.9 & 10.247 & 0.387 \\
\hline & 14 & 87 & 5 & $X_{5}$ & 0.6 & 12.653 & 0.132 \\
\hline & 15 & 75 & 4 & $X_{4}$ & 0.6 & 11.214 & 0.101 \\
\hline & 16 & 160 & 6 & $X_{8}$ & 0.8 & 20.237 & 0.518 \\
\hline & 18 & 140 & 6 & $X_{7}$ & 0.7 & 0.346 & 0.007 \\
\hline & 20 & 170 & 7 & $X_{6}$ & 0.8 & 12.731 & 0.346 \\
\hline & 24 & 150 & 6 & $X_{8}$ & 0.8 & 18.281 & 0.439 \\
\hline & 26 & 162 & 6 & $X_{7}$ & 0.8 & 9.800 & 0.254 \\
\hline & 28 & 155 & 6 & $X_{6}$ & 0.8 & 13.547 & 0.336 \\
\hline & 32 & 88 & 4 & $X_{5}$ & 0.6 & 5.889 & 0.062 \\
\hline \multirow{15}{*}{$\begin{array}{l}\frac{0}{E} \\
\frac{1}{2} \\
\frac{1}{02} \\
0 \\
0\end{array}$} & 5 & 80 & 5 & $X_{4}$ & 0.6 & 28.823 & 0.277 \\
\hline & 6 & 93 & 5 & $X_{5}$ & 0.6 & 5.282 & 0.059 \\
\hline & 8 & 50 & 4 & $X_{2}$ & 0.5 & 62.994 & 0.315 \\
\hline & 12 & 86 & 5 & $X_{6}$ & 0.6 & 10.562 & 0.109 \\
\hline & 13 & 110 & 5 & $X_{5}$ & 0.7 & 5.321 & 0.082 \\
\hline & 17 & 94 & 5 & $X_{8}$ & 0.6 & 20.207 & 0.228 \\
\hline & 19 & 97 & 5 & $X_{7}$ & 0.6 & 9.798 & 0.114 \\
\hline & 21 & 120 & 5 & $X_{3}$ & 0.7 & 15.772 & 0.265 \\
\hline & 22 & 113 & 5 & $X_{3}$ & 0.7 & 10.974 & 0.174 \\
\hline & 23 & 118 & 5 & $X_{3}$ & 0.7 & 10.201 & 0.169 \\
\hline & 25 & 74 & 4 & $X_{8}$ & 0.6 & 34.166 & 0.303 \\
\hline & 27 & 87 & 5 & $X_{7}$ & 0.6 & 9.771 & 0.102 \\
\hline & 29 & 125 & 5 & $X_{3}$ & 0.7 & 15.767 & 0.276 \\
\hline & 30 & 220 & 7 & $X_{3}$ & 0.9 & 15.783 & 0.625 \\
\hline & 31 & 123 & 5 & $X_{2}$ & 0.7 & 13.586 & 0.234 \\
\hline Total & - & 3961 & - & - & - & - & 8.016 \\
\hline
\end{tabular}

* Rial (Iran's formal currency unit) is converted to Dollar; 35000 Rials is equivalent to 1 USD.

$$
\begin{aligned}
& X_{0}^{2}=\sum_{i=1}^{k} \frac{\left(O_{i}-E_{i}\right)^{2}}{E_{i}}, \\
& K \text { (integer) } \approx \sqrt{n} \geq 5,
\end{aligned}
$$

where $s$ is the number of estimated parameters (for normal distribution $s=2$ ), $O_{i}$ is accepted error level
(0.05 in this paper), $\alpha_{i}$ is observed frequency in the $i$ th class interval, $E_{i}=n \cdot p_{i}$ is expected frequency in the $i$ th class interval, and $p_{i}=1 / k$ is theoretical probability [35].

The normality test results are summarized in Table 7. Goodness of fit is approved since Eq. (6) is satisfied in all data sets. Therefore, all data 
Table 6. Collected data (dependent variables), estimated amounts of wastage, end relative errors in the developed models for the studied materials.

\begin{tabular}{|c|c|c|c|c|c|c|c|c|c|c|c|c|c|c|}
\hline \multirow[t]{2}{*}{ Site no. } & \multirow[b]{2}{*}{$Y_{\text {Site }}^{\text {Rebar }}$} & \multicolumn{2}{|l|}{ Rebar } & \multicolumn{3}{|c|}{ Concrete } & \multicolumn{3}{|c|}{ Brick } & \multicolumn{5}{|c|}{ Cement } \\
\hline & & $Y_{\text {Model_1_ }}^{\text {Rebar }}$ & $\mid$ Error $\left.\right|^{*}$ & $Y_{\text {Site }}^{\text {Concrete }}$ & ${ }^{e} Y_{\text {Model_1 }}^{\text {Concrete }}$ & |Error| & $Y_{\text {Site }}^{\text {Brick }}$ & $Y_{\text {Model_1 }}^{\text {Brick }}$ & $\mid$ Error $\mid$ & $\mid Y_{\text {Site }}^{\text {Cement }}$ & $Y_{\text {Model_1 }}^{\text {Cement }}$ & |Error| & $\mid \boldsymbol{Y}_{\text {Model_2 }}^{\text {Cement }}$ & $\mid$ Error $\mid$ \\
\hline 1 & 1.000 & 0.973 & 0.027 & 2.500 & 2.818 & 0.127 & 5.800 & 6.407 & 0.105 & 5.660 & 5.600 & 0.011 & 5.885 & 0.040 \\
\hline 2 & 1.300 & 0.973 & 0.252 & 2.670 & 2.492 & 0.067 & 5.600 & 6.407 & 0.144 & 7.400 & 7.594 & 0.026 & 5.581 & 0.246 \\
\hline 3 & 1.200 & 1.302 & 0.085 & 2.250 & 1.672 & 0.257 & 6.800 & 6.407 & 0.058 & 16.670 & 16.868 & 0.012 & 6.519 & 0.609 \\
\hline 4 & 1.100 & 1.098 & 0.002 & 1.220 & 1.151 & 0.056 & 8.000 & 6.407 & 0.199 & 14.500 & 14.343 & 0.011 & 6.885 & 0.525 \\
\hline 5 & 1.500 & 1.352 & 0.099 & 6.470 & 5.068 & 0.217 & 5.000 & 5.049 & 0.010 & 6.670 & 7.880 & 0.181 & 8.663 & 0.299 \\
\hline 6 & 1.600 & 1.823 & 0.139 & 3.350 & 4.074 & 0.216 & 5.700 & 5.140 & 0.098 & 6.670 & 6.446 & 0.034 & 10.074 & 0.510 \\
\hline 7 & 1.300 & 1.041 & 0.199 & 2.700 & 3.430 & 0.270 & 6.800 & 6.407 & 0.058 & 3.330 & 3.757 & 0.128 & 5.072 & 0.523 \\
\hline 8 & 1.750 & 1.630 & 0.069 & 5.450 & 5.459 & 0.002 & No data & & & 5.250 & 5.047 & 0.039 & 8.515 & 0.622 \\
\hline 9 & 1.000 & 0.763 & 0.237 & 2.290 & 2.388 & 0.043 & 4.000 & 3.533 & 0.117 & 10.000 & 10.578 & 0.058 & 7.001 & 0.300 \\
\hline 10 & 0.800 & 0.763 & 0.046 & 2.500 & 2.844 & 0.138 & 5.000 & 3.624 & 0.275 & 7.800 & 7.787 & 0.002 & 6.144 & 0.212 \\
\hline 11 & 1.000 & 0.800 & 0.200 & 5.500 & 5.499 & 0.000 & 7.200 & 5.140 & 0.286 & 6.670 & 6.668 & 0.000 & 4.697 & 0.296 \\
\hline 12 & 1.730 & 1.389 & 0.197 & 9.330 & 9.012 & 0.034 & 5.000 & 5.140 & 0.028 & No data & & & & \\
\hline 13 & 1.710 & 1.823 & 0.066 & 4.760 & 3.853 & 0.191 & 3.500 & 3.624 & 0.035 & 8.000 & 7.801 & 0.025 & 9.925 & 0.241 \\
\hline 14 & 1.200 & 1.234 & 0.028 & 1.810 & 2.253 & 0.245 & 4.000 & 3.533 & 0.117 & 4.000 & 3.880 & 0.030 & 6.351 & 0.588 \\
\hline 15 & 1.150 & 0.831 & 0.277 & 4.000 & 3.235 & 0.191 & 15.200 & 16.400 & 0.079 & 7.000 & 7.300 & 0.043 & 6.653 & 0.050 \\
\hline 16 & 0.500 & 0.504 & 0.008 & 2.650 & 2.128 & 0.197 & No data & & & 7.000 & 7.130 & 0.019 & 3.750 & 0.464 \\
\hline 17 & 1.000 & 1.161 & 0.161 & 3.950 & 4.886 & 0.237 & 11.110 & 11.703 & 0.053 & 5.830 & 5.860 & 0.005 & 8.979 & 0.540 \\
\hline 18 & 1.140 & 1.166 & 0.023 & 2.480 & 2.388 & 0.037 & 5.100 & 3.624 & 0.289 & 10.000 & 8.673 & 0.133 & 7.063 & 0.294 \\
\hline 19 & 2.000 & 1.823 & 0.089 & 4.170 & 4.847 & 0.162 & 10.000 & 7.923 & 0.208 & 9.670 & 9.236 & 0.045 & 9.717 & 0.005 \\
\hline 20 & 0.900 & 0.664 & 0.262 & 6.060 & 6.020 & 0.007 & 7.500 & 7.923 & 0.056 & No data & & & & \\
\hline 21 & 1.790 & 1.823 & 0.018 & 3.960 & 4.548 & 0.148 & 7.000 & 7.923 & 0.132 & 10.000 & 11.070 & 0.107 & 8.739 & 0.126 \\
\hline 22 & 1.800 & 1.823 & 0.013 & 3.750 & 4.639 & 0.237 & 17.600 & 16.400 & 0.068 & 13.330 & 10.512 & 0.211 & 9.331 & 0.300 \\
\hline 23 & 2.000 & 1.823 & 0.089 & 4.050 & 4.574 & 0.129 & 10.000 & 10.187 & 0.019 & 13.330 & 10.910 & 0.182 & 9.364 & 0.298 \\
\hline 24 & 0.700 & 0.504 & 0.280 & 2.650 & 2.258 & 0.148 & No data & & & 6.000 & 6.333 & 0.056 & 4.264 & 0.289 \\
\hline 25 & 1.200 & 1.229 & 0.024 & 6.330 & 5.147 & 0.187 & 5.000 & 3.624 & 0.275 & 6.670 & 6.170 & 0.075 & 8.590 & 0.288 \\
\hline 26 & 1.140 & 1.166 & 0.023 & 1.850 & 2.102 & 0.136 & 7.640 & 7.923 & 0.037 & 10.500 & 10.427 & 0.007 & 5.461 & 0.480 \\
\hline 27 & 2.000 & 1.823 & 0.089 & 5.830 & 4.977 & 0.146 & 8.570 & 7.923 & 0.075 & 6.670 & 8.438 & 0.265 & 9.795 & 0.469 \\
\hline 28 & 1.000 & 0.732 & 0.268 & 7.760 & 6.215 & 0.199 & 7.510 & 7.923 & 0.055 & No data & & & & \\
\hline 29 & 1.790 & 1.823 & 0.018 & 4.790 & 4.483 & 0.064 & 3.330 & 3.624 & 0.088 & 12.000 & 11.469 & 0.044 & 8.668 & 0.278 \\
\hline 30 & 1.700 & 1.687 & 0.008 & 3.200 & 3.246 & 0.014 & 8.570 & 7.923 & 0.075 & 13.330 & 15.234 & 0.143 & 6.206 & 0.534 \\
\hline 31 & 2.000 & 1.562 & 0.219 & 3.910 & 4.509 & 0.153 & 7.510 & 7.923 & 0.055 & 9.330 & 8.963 & 0.039 & 8.940 & 0.042 \\
\hline 32 & 1.400 & 1.302 & 0.070 & 2.500 & 2.240 & 0.104 & 3.330 & 3.624 & 0.088 & 5.330 & 5.865 & 0.100 & 6.904 & 0.295 \\
\hline
\end{tabular}

*All errors are in terms of relative percent.

Table 7. Checking normality test results for each accepted model.

\begin{tabular}{|c|c|c|c|c|c|c|c|c|c|c|c|c|c|}
\hline \multirow[b]{2}{*}{ Material } & \multirow[b]{2}{*}{$\boldsymbol{K}$} & \multirow[b]{2}{*}{ Mean } & \multirow{2}{*}{$\begin{array}{l}\text { Standard } \\
\text { deviation }\end{array}$} & \multicolumn{6}{|c|}{$O_{i}$} & \multirow[b]{2}{*}{$X_{0}^{2}$} & \multirow[b]{2}{*}{$X_{\alpha, k-s-1}^{2}$} & \multirow[b]{2}{*}{$<X_{\alpha, k-s-1}^{2} ?$} & \multirow[b]{2}{*}{ Normality } \\
\hline & & & & $O_{1}$ & $\mathrm{O}_{2}$ & $\mathrm{O}_{3}$ & $\mathrm{O}_{4}$ & $\mathrm{O}_{5}$ & $\mathrm{O}_{6}$ & & & & \\
\hline Rebar & 6 & 1.373 & 0.419 & 4 & 8 & 6 & 2 & 7 & 5 & 4.378 & 6.251 & Yes & Accepted \\
\hline Concrete & 6 & 3.959 & 1.863 & 3 & 10 & 5 & 4 & 4 & 6 & 5.875 & 6.251 & Yes & Accepted \\
\hline Brick & 6 & 7.151 & 3.289 & 3 & 9 & 4 & 6 & 4 & 3 & 5.552 & 6.251 & Yes & Accepted \\
\hline Cement & 6 & 8.573 & 3.327 & 5 & 9 & 3 & 3 & 3 & 6 & 5.966 & 6.251 & Yes & Accepted \\
\hline
\end{tabular}


sets are distributed normally and using MLR is allowed for quantification of all studied wasted materials $[9,35,36]$.

\section{Quantitative models}

In the first part of the study, by means of IBM SPSS, dependent variable (BMW weight percent) and independent variables (contract type, locality, $S$, and FA) were analyzed for the studied BMs. Several combinations of the variables were examined, correlated variables were determined, and the best model satisfying acceptance criteria was found based on trial and error method. The general form of quantitative models based on MLR is as Eq. (9):

$$
Y_{\text {Model }}^{\text {Material }}=\text { Const. }+\left(\sum_{i=1}^{8} \beta_{i} X_{i}\right)+E,
$$

where Const. is the constant, $\beta_{i}$ is the coefficient of independent parameter $X_{i}$, and $E$ is the error term.

\subsection{Acceptance criteria}

Acceptance criteria were derived from the most current and related papers and statistical references.

\subsubsection{Validation}

The following are the criteria of a valid model:

- Considering the sample size, parameters $F$ and $|t|$ calculated by IBM SPSS for each model must be bigger than 2.15 and 2.03, respectively [36].

- $P$-value for the model must be equal to or less than 0.05 to find the best MLR for a significance level of $\alpha=0.05[9,37]$.

\subsubsection{Verification}

Models must be felicitous for residential buildings, which are not studied in the conducted survey.

\subsection{Valid and verified models}

Validation and verification have to be performed separately for both parts of the study.

\subsubsection{The first part of the study}

Based on the delineated procedure, the following valid and verified models are developed to estimate BMW. The data used for this regression are presented in Table 5 (parameters FA $(A)$, number of stories $(S)$, contract type $\left(X_{1}\right)$, and location $\left(X_{2}\right.$ to $\left.X_{8}\right)$ ) and Table 6 (amounts of wasted rebar, concrete, brick, and cement in sites $\left(Y_{\text {Site }}^{\text {Rebar }}, Y_{\text {Site }}^{\text {Concrete }}, Y_{\text {Site }}^{\text {Brick }}\right.$, and $\left.Y_{\text {Site }}^{\text {Cement }}\right)$ ).

$$
\begin{aligned}
Y_{\text {Model_1 }}^{\text {Rebar }}= & 2.163-0.068 S-0.589 X_{1}-0.261 X_{4} \\
& -0.471 X_{5}-0.434 X_{6}-0.662 X_{8},
\end{aligned}
$$

$$
\begin{aligned}
Y_{\text {Model_1 }}^{\text {Concrete }}= & 6.110-1.302 A-1.899 X_{1}-0.825 X_{5} \\
& +4.022 X_{6}, \\
Y_{\text {Model_1 }}^{\text {Brick }}= & 7.923-1.516 X_{1}-2.874 X_{4}-2.783 X_{5} \\
& +3.780 X_{7}+8.477 X_{8}, \\
Y_{\text {Model_1 }}^{\text {Cement }}= & 11.026+7.974 A-1.905 S-2.087 X_{1} \\
& -2.346 X_{2}-2.471 X_{5}-9.491 X_{6} \\
& -3.137 X_{8} .
\end{aligned}
$$

\subsubsection{Results of the previous researches}

Kern et al. [9] conducted an analogous research in Brazil by studying 18 high-rise buildings and suggested Eq. (14) for C\&DW generation:

$$
\begin{aligned}
\text { Waste }(\text { Ton })= & 5202.886+5138.519 F R+1.411 F A \\
& +22.968 E I C+375.155 C S \\
& -783.296 W R+E
\end{aligned}
$$

where $F R$ is the number of on-ground floors to total number of floors ratio, $W R$ is recycled materials percentage, $C S$ is the construction system $(1,2$, and 3 for conventional, ordinary, and industrial systems, respectively), and $E I C$ is the economic index of compaction calculated by Eq. (15):

$$
E I C=\frac{0.02 \times \sqrt{F A \times \pi}}{\left(\text { Plan perimeter }+\frac{\text { Number of edges }}{2}\right)} .
$$

Moreover, Ding and Xiao [15] suggested the wastage of concrete, brick, and rebar in 2013 in Shanghai to be 1,5 , and $3 \%$ by weight, respectively. Also, Cochran et al. [38] calculated the wastage of concrete, rebar, and wood equal to $22.9,0.9$, and $6.4 \mathrm{~kg} / \mathrm{m}^{2}$, respectively.

\subsubsection{The second part of the study and theoretical soundness of the hypothesis}

Incentive plans have already been implemented successfully in the Iranian agriculture industry (but not in construction industry yet) in order to compel farmers to cultivate substitute crops, i.e., corn instead of what they regularly grow, i.e., wheat. Based on the results of the conducted questionnaire survey, this method can potentially be helpful in reducing materials waste and might be an independent variable to explain building wastage. This is basically why the authors decided to test usefulness of this method and consider FI $(C)$ in this part of study. To avoid duplication, parameters $A$ and locality, which are involved in calculation of FI, are omitted. The data used for this regression are 
presented in Table 5 (parameters contract type $\left(X_{1}\right)$ and FI or $C$ ). The following models are accepted after accomplishing the expounded procedure in the antecedent section:

$$
\begin{aligned}
& Y_{\text {Model_2 }}^{\text {Rebar }}=1.513-0.134 X_{1}-0.575 C, \\
& Y_{\text {Model_2 }}^{\text {Concrete }}=5.010-2.110 X_{1}-2.535 C, \\
& Y_{\text {Model_2 }}^{\text {Brick }}=7.615-2.438 X_{1}-3.425 C, \\
& Y_{\text {Model_2 }}^{\text {Cement }}=10.956-3.249 X_{1}-0.100 S-6.480 C .
\end{aligned}
$$

\subsubsection{Contract type quantitative effect}

Quantitative effect of each independent variable, i.e., contract type, on BMW can be determined by analyzing its coefficient in Eqs. (10) to (13) and (16) to (19). Considering the values attributed to the parameter $X_{1}$, using cost-plus contract increases materials wastage, as depicted in Figure 2, for both scenarios of implementing or not implementing FI program.

\subsubsection{Assigning FI to the most sensitive material and} its evaluation in the second part of the study

According to the discussed characteristics of FI, it can be assigned to one of the BMs, and since its increase is a managerial tool for attain more reduction in waste, it should be attributed to the most sensitive material. This is the concept of elasticity analysis $[2,39,40]$. According to the definition of elasticity [26], the elasticity of BMW $(Y)$ to FI $(C)$ can be written as:

$$
E l_{Y C}=\frac{\left(\frac{\partial Y}{Y}\right)}{\left(\frac{\partial C}{C}\right)}=\frac{\left(\frac{\Delta Y}{Y}\right)}{\left(\frac{\Delta C}{C}\right)}=\frac{\left(\frac{Y_{2}-Y_{1}}{Y_{1}}\right)}{\left(\frac{C_{2}-C_{1}}{C_{1}}\right)} .
$$

The increase in elasticity of the studied BMW to FI is calculated for all buildings in Table 8 . The average elasticity is used to calculate the total amount of BMW reduction after $1 \%$ increase in the initial incentive. The results are summarized in Table 9. If FI increases by up to $1 \%$, the amount of cement waste will be reduced by up to $1.56 \%$, which is more than the reduction in other materials wastage. Furthermore, cement is

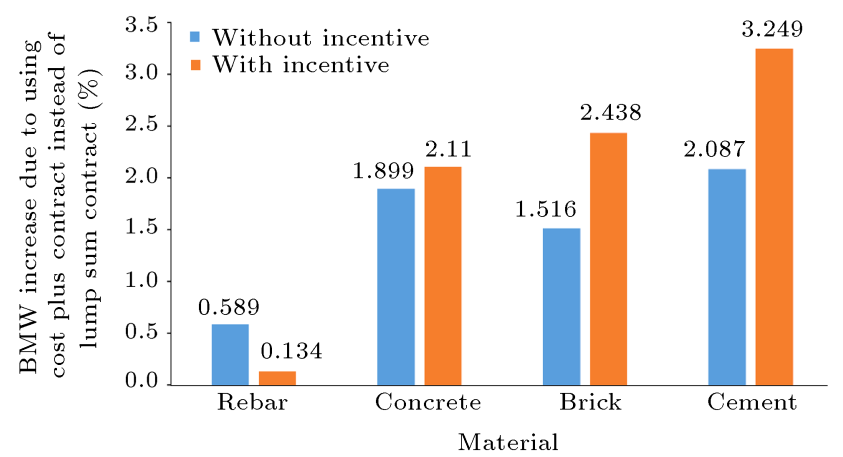

Figure 2. Quantitative effect of contract type on materials waste. wasted more than other materials. As a corollary, attribution of the proposed FI to cement is legitimate.

Benefit to cost ratio is used to evaluate the economic viability of the proposed FI. One unit of FI will result in $6.48 \%$ CWR according to Eq. (19). According to the last available data, annually, 3503 permits are issued for residential buildings construction, $4.7 \times 10^{6} \mathrm{~m}^{2}$ residential building is constructed in Tehran, and the government allocates $100 \mathrm{~kg}$ cement per FA [41,42]. Furthermore, one ton of cement produced emits $933.80 \mathrm{~kg} \mathrm{CO}_{2}$ and avoiding emission of 1 ton of $\mathrm{CO}_{2}$ using post combustion capture costs 107.4 $€$ (about \$119) [43]. Therefore, cost and benefit $\left(C_{1}\right.$ and $\left.B_{1}\right)$ of one unit of the proposed FI, $\$ 1000$, can be calculated:

$$
\begin{aligned}
C_{1}= & \frac{\text { unit cost }(\$) \times \text { permits number }}{\text { total constructed area }\left(\mathrm{m}^{2}\right)} \\
= & \frac{1000 \times 3503}{4.7 \times 10^{6}}=0.745\left(\frac{\$}{\mathrm{~m}^{2}}\right), \\
B_{1}= & 6.48 \% \times \frac{0.1 \text { ton cement }}{1 \mathrm{~m}^{2} F A} \times \frac{0.9338 \text { ton } \mathrm{CO}_{2}}{1 \text { ton cement }} \\
& \times \frac{\$ 119}{1 \text { ton avoided } \mathrm{CO}_{2}}=0.720\left(\frac{\$}{\mathrm{~m}^{2}}\right) .
\end{aligned}
$$

The cost of increasing FI by $x$ percent $(\Delta C)$ and benefit gained from corresponding CWR (cost saving, $\Delta B$ ) should be considered too. According to Table 5, the average FI assigned to buildings equals $8.016 \times$ $1000 / 3961$ or $\$ 2.023$ per $1.0 \mathrm{~m}^{2} \mathrm{FA}$ and according to Table 9, 1\% increase in FI results in $1.56 \%$ CWR:

$$
\begin{aligned}
\Delta C= & \frac{x}{100} \times 2.023=0.020 x\left(\frac{\$}{\mathrm{~m}^{2}}\right), \\
\Delta B= & \frac{x}{100} \times 1.56 \times \frac{0.1 \text { ton cement }}{1 \mathrm{~m}^{2} F A} \\
& \times \frac{\$ 36.281}{1 \text { ton cement }}=0.057 x\left(\frac{\$}{\mathrm{~m}^{2}}\right) .
\end{aligned}
$$

Cement costs $\$ 36.281$ per ton in Tehran [42]. Benefit to cost ratio equals:

$$
\frac{\text { Benefit }}{\text { Cost }}=\frac{B_{1}+\Delta B}{C_{1}+\Delta C}=\frac{0.720+0.057 x}{0.745+0.020 x}
$$

$1 \%$ increase in $F I \cong 1.56 \% C W R \rightarrow$

$$
\begin{aligned}
& \frac{\text { Benefit }}{\text { Cost }}=\frac{0.720+0.057 x}{0.745+0.020 x} \geq 1 \rightarrow \\
& x \geq 0.676 \% \rightarrow \\
& C W R \geq 1.56 \times 0.676=1.055 \% .
\end{aligned}
$$


Table 8. Elasticity of studied BMs to one percent increase in the proposed FI.

\begin{tabular}{|c|c|c|c|c|}
\hline $\begin{array}{l}\text { Building } \\
\text { no. }\end{array}$ & $\begin{array}{c}\text { Rebar waste } \\
\text { elasticity }\end{array}$ & $\begin{array}{c}\text { Concrete waste } \\
\text { elasticity }\end{array}$ & $\begin{array}{c}\text { Brick waste } \\
\text { elasticity }\end{array}$ & $\begin{array}{c}\text { Cement waste } \\
\text { elasticity }\end{array}$ \\
\hline 1 & -0.117 & -0.207 & -0.120 & -0.234 \\
\hline 2 & -0.111 & -0.238 & -0.154 & -0.220 \\
\hline 3 & -0.141 & -0.554 & -0.248 & -0.191 \\
\hline 4 & -0.349 & -1.386 & -0.286 & -0.298 \\
\hline 5 & -0.123 & -0.042 & -0.073 & -0.104 \\
\hline 6 & -0.021 & -0.045 & -0.035 & -0.057 \\
\hline 7 & -0.043 & -0.092 & -0.049 & -0.191 \\
\hline 8 & -0.022 & -0.032 & - & -0.084 \\
\hline 9 & -0.126 & -0.242 & -0.188 & -0.142 \\
\hline 10 & -0.118 & -0.166 & -0.112 & -0.136 \\
\hline 11 & -0.245 & -0.196 & -0.203 & -0.414 \\
\hline 12 & -0.054 & -0.044 & -0.112 & - \\
\hline 13 & -0.028 & -0.044 & -0.080 & -0.066 \\
\hline 14 & -0.026 & -0.077 & -0.047 & -0.089 \\
\hline 15 & -0.051 & -0.064 & -0.023 & -0.093 \\
\hline 16 & -0.596 & -0.496 & - & -0.480 \\
\hline 17 & -0.131 & -0.146 & -0.070 & -0.253 \\
\hline 18 & -0.097 & -0.196 & -0.129 & -0.124 \\
\hline 19 & -0.033 & -0.069 & -0.039 & -0.076 \\
\hline 20 & -0.274 & -0.179 & -0.196 & - \\
\hline 21 & -0.085 & -0.170 & -0.130 & -0.172 \\
\hline 22 & -0.080 & -0.169 & -0.049 & -0.122 \\
\hline 23 & -0.075 & -0.163 & -0.089 & -0.127 \\
\hline 24 & -0.398 & -0.464 & - & -0.524 \\
\hline 25 & -0.086 & -0.072 & -0.123 & -0.175 \\
\hline 26 & -0.128 & -0.348 & -0.114 & -0.157 \\
\hline 27 & -0.029 & -0.044 & -0.041 & -0.099 \\
\hline 28 & -0.225 & -0.128 & -0.178 & - \\
\hline 29 & -0.089 & -0.146 & -0.284 & -0.149 \\
\hline 30 & -0.211 & -0.495 & -0.250 & -0.304 \\
\hline 31 & -0.067 & -0.152 & -0.107 & -0.163 \\
\hline 32 & -0.081 & -0.057 & -0.058 & -0.068 \\
\hline Average & -0.133 & -0.216 & -0.124 & -0.183 \\
\hline
\end{tabular}

Table 9. Total waste reduction of studied BMs per one percent increase in the proposed FI.

\begin{tabular}{lccc}
\hline Material & Elasticity & $\begin{array}{c}\text { Average } \\
\text { wastage (\%) }\end{array}$ & $\begin{array}{c}\text { Total waste } \\
\text { reduction (\%) }\end{array}$ \\
\hline Rebar & -0.133 & 1.32 & 0.18 \\
Concrete & -0.216 & 3.96 & 0.86 \\
Brick & -0.124 & 7.15 & 0.89 \\
Cement & -0.183 & 8.57 & 1.56 \\
\hline
\end{tabular}


Table 10. Annual reduction in raw materials as well as energy consumption and air pollutants emission per one percent increase in FI.

\begin{tabular}{lccc}
\hline Indicator & & Reduction & Unit \\
\hline Raw materials consumption & & 12024.48 & Ton \\
Electrical energy consumption & & 0.732 & Million kWh \\
Heat energy consumption & & 6.065 & Billion kcal \\
Air pollutants emission & $\mathrm{CO}_{2}$ & 6846.622 & Ton \\
& $\mathrm{NO}_{x}$ & 18.110 & Ton \\
& $\mathrm{SO}_{2}$ & 3830.237 & Ton \\
& $\mathrm{SPM}$ & 730.267 & Ton \\
Total air pollutants emission & & 11425.236 & Ton \\
\hline
\end{tabular}

Thus, FI is economically viable when cement waste is reduced by more than $1.055 \%$; therefore, the initial amount of FI can be increased proportional to this amount according to Eq. (27).

If $C W R \geq 1.055 \%$ (1\% increase in $F I \cong 1.56 \% C W R$ )

$$
\begin{aligned}
& \rightarrow T F I=(1+x) \times D C=\left(1+\frac{C W R}{1.56 \times 100}\right) \\
& \times D C=\left(1+\frac{C W R}{156}\right) \times 0.2 \times K \times P \times F A,
\end{aligned}
$$

where TFI is total FI in terms of $\$$ and:

$$
C W R=\% C W_{1}-\% C W_{2} \text {, }
$$

where $\% C W_{1}$ is common cement waste weight percent asked of/estimated by project manager in projects without implementation of incentive based program, and $\% C W_{2}$ is cement waste weight percent after implementing FI based program.

On the other hand, when CWR is less than $1.055 \%$, the contractor will be paid only the price of cement which is saved and not wasted according to Eq. (29):

$$
\text { If } \begin{aligned}
C W R & <1.055 \% \rightarrow T F I=\frac{C W R}{100} \\
& \times \frac{\$ 36.281}{1 \text { ton cement }} \times \frac{0.1 \text { ton cement }}{1 \mathrm{~m}^{2} F A} \\
& \times F A\left(\mathrm{~m}^{2}\right) \times S=0.036 \times C W R \times F A \times S .
\end{aligned}
$$

Finally:

$$
\begin{aligned}
& T F I= \\
& \begin{cases}\left(1+\frac{C W R}{156}\right) \times 0.2 \times K \times P \times F A & C W R \geq 1.055 \% \\
0.036 \times C W R \times F A \times S & C W R<1.055 \%(30)\end{cases}
\end{aligned}
$$

For environmental evaluation, considering $100 \mathrm{~kg}$ cement allocated per $1.0 \mathrm{~m}^{2} \mathrm{FA}$ and $4.7 \times 10^{6} \mathrm{~m}^{2}$ annually constructed residential building in Tehran, $1.56 \%$ reduction in cement waste due to $1 \%$ increase in the amount of FI equals 7332 tons of CWR annually:

$$
\begin{aligned}
1.56 \% & \times \frac{0.1 \text { ton cement }}{1 \mathrm{~m}^{2} F A} \times 4.7 \times 10^{6}\left(\frac{\mathrm{m}^{2} F A}{\text { year }}\right) \\
& =7332 \frac{\text { ton cement }}{\text { year }} .
\end{aligned}
$$

Table 10 shows reductions in raw materials and energy consumption, and air pollutants emission per $1 \%$ increase in the proposed FI by multiplying 7332 tons of CWR by the environmental indicators in Table 1.

\section{Checking models}

\subsection{Validation}

All models are valid, because they satisfy the validation criteria (Tables 11 and 12). Parameters are defined in Table 13.

\subsection{Verification}

4.2.1. Verification of the models developed in the first part of the study

Thirty-two new residential buildings (equal to the primary sample size) were studied according to the described procedure in Section 2.1 and the BMs wastages in sites were calculated $\left(Y_{\text {Site }}\right)$. Afterwards, Eqs. (10) to (13) were applied to the calculation of the estimated wastage of each material ( $\left.Y_{\text {Model_1 }}\right)$. The relative errors of new residential buildings are presented in Table 14. All models have relative errors less than $30 \%$, suggesting that the models are verified.

\subsubsection{Verification of the models developed in the second part of the study}

To implement the plan in public and private construction projects, it is necessary for the governmental organizations, i.e., municipalities and clients, to finance the program. To verify the models in the second 
Table 11. Validation of the proposed models (part one).

\begin{tabular}{|c|c|c|c|c|c|c|c|}
\hline & $\begin{array}{l}\text { Equation } \\
\text { number }\end{array}$ & Material & $F$ & $P$-value & Is $F>2.15$ and $P$-value $\leq 0.05 ?$ & $R^{2}$ & $R_{\text {Adjusted }}^{2}$ \\
\hline \multirow{4}{*}{$\begin{array}{l}\text { First part } \\
\text { of study }\end{array}$} & 11 & Rebar & 51.184 & 0.000 & Yes & 0.925 & 0.907 \\
\hline & 12 & Concrete & 30.191 & 0.000 & Yes & 0.817 & 0.790 \\
\hline & 13 & Brick & 65.108 & 0.000 & Yes & 0.934 & 0.920 \\
\hline & 14 & Cement & 32.117 & 0.000 & Yes & 0.904 & 0.875 \\
\hline \multirow{4}{*}{$\begin{array}{c}\text { Second part } \\
\text { of study }\end{array}$} & 15 & Rebar & 27.393 & 0.000 & Yes & 0.763 & 0.735 \\
\hline & 16 & Concrete & 42.018 & 0.000 & Yes & 0.832 & 0.812 \\
\hline & 17 & Brick & 21.741 & 0.000 & Yes & 0.731 & 0.697 \\
\hline & 18 & Cement & 64.685 & 0.000 & Yes & 0.791 & 0.741 \\
\hline
\end{tabular}

Table 12. Validation of the proposed models (part two).

\begin{tabular}{|c|c|c|c|c|c|c|c|}
\hline & $\begin{array}{l}\text { Dependent } \\
\text { variable }\end{array}$ & $\begin{array}{c}\text { Constant or } \\
\text { independent variables }\end{array}$ & $P$-value & $t$ & $\begin{array}{c}\text { Is }|t|>2.03 \text { and } \\
P \text {-value } \leq 0.05 ?\end{array}$ & $\begin{array}{l}\text { Standard } \\
\text { error }\end{array}$ & Beta \\
\hline \multirow{26}{*}{ 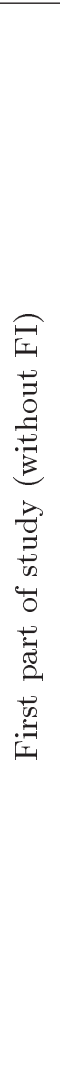 } & \multirow{7}{*}{$Y_{\text {Model_1 }}^{\text {Rebar }}$} & Constant & 0.000 & 13.475 & Yes & 0.057 & \\
\hline & & S & 0.031 & -2.280 & Yes & 0.030 & -0.134 \\
\hline & & $X_{1}$ & 0.000 & -12.003 & Yes & 0.049 & -0.699 \\
\hline & & $X_{4}$ & 0.002 & -3.448 & Yes & 0.076 & -0.205 \\
\hline & & $X_{5}$ & 0.000 & -6.376 & Yes & 0.074 & -0.370 \\
\hline & & $X_{6}$ & 0.004 & -3.166 & Yes & 0.137 & -0.180 \\
\hline & & $X_{8}$ & 0.000 & -9.210 & Yes & 0.072 & -0.520 \\
\hline & \multirow{5}{*}{$Y_{\text {Model_1 }}^{\text {Concrete }}$} & Constant & 0.000 & 16.370 & Yes & 0.073 & \\
\hline & & A & 0.000 & -4.360 & Yes & 0.099 & -0.417 \\
\hline & & $X_{1}$ & 0.000 & -7.501 & Yes & 0.053 & -0.666 \\
\hline & & $X_{5}$ & 0.032 & -2.256 & Yes & 0.066 & -0.192 \\
\hline & & $X_{6}$ & 0.000 & 5.615 & Yes & 0.076 & 0.492 \\
\hline & \multirow[t]{6}{*}{$Y_{\text {Model_1 }}^{\text {Brick }}$} & Constant & 0.000 & 24.291 & Yes & 0.026 & \\
\hline & & $X_{1}$ & 0.001 & -3.935 & Yes & 0.085 & -0.223 \\
\hline & & $X_{4}$ & 0.000 & -5.147 & Yes & 0.058 & -0.291 \\
\hline & & $X_{5}$ & 0.000 & -5.039 & Yes & 0.052 & -0.282 \\
\hline & & $X_{7}$ & 0.000 & 6.845 & Yes & 0.052 & 0.383 \\
\hline & & $X_{8}$ & 0.000 & 11.058 & Yes & 0.067 & 0.632 \\
\hline & \multirow[t]{8}{*}{$Y_{\text {Model_1 }}^{\text {Cement }}$} & Constant & 0.000 & 7.365 & Yes & 0.097 & \\
\hline & & A & 0.000 & 10.220 & Yes & 0.076 & -0.504 \\
\hline & & $S$ & 0.000 & -5.070 & Yes & 0.043 & -0.331 \\
\hline & & $X_{1}$ & 0.000 & -4.709 & Yes & 0.025 & -0.270 \\
\hline & & $X_{2}$ & 0.001 & -3.756 & Yes & 0.063 & -0.259 \\
\hline & & $X_{5}$ & 0.001 & -3.727 & Yes & 0.039 & -0.524 \\
\hline & & $X_{6}$ & 0.000 & -7.090 & Yes & 0.031 & -0.329 \\
\hline & & $X_{8}$ & 0.000 & -4.973 & Yes & 0.080 & 0.154 \\
\hline \multirow{13}{*}{ 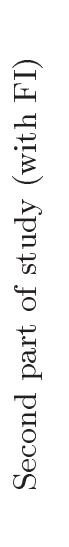 } & \multirow[t]{3}{*}{$Y_{\text {Model_2 }}^{\text {Rebar }}$} & Constant & 0.000 & 56.548 & Yes & 0.027 & \\
\hline & & $X_{1}$ & 0.001 & -4.219 & Yes & 0.032 & -0.514 \\
\hline & & C & 0.000 & -4.858 & Yes & 0.024 & -0.592 \\
\hline & \multirow{3}{*}{$Y_{\text {Model_2 }}^{\text {Concrete }}$} & Constant & 0.000 & 22.298 & Yes & 0.025 & \\
\hline & & $X_{1}$ & 0.000 & -7.908 & Yes & 0.067 & -0.812 \\
\hline & & C & 0.021 & -2.552 & Yes & 0.099 & -0.262 \\
\hline & \multirow[t]{3}{*}{$Y_{\text {Model_2 }}^{\text {Brick }}$} & Constant & 0.000 & 19.981 & Yes & 0.081 & \\
\hline & & $\mathrm{X} 1$ & 0.000 & -5.640 & Yes & 0.032 & -0.749 \\
\hline & & C & 0.050 & -2.108 & Yes & 0.025 & -0.280 \\
\hline & \multirow[t]{4}{*}{$Y_{\text {Model_2 }}^{\text {Cement }}$} & Constant & 0.020 & 6.981 & Yes & 0.037 & \\
\hline & & $\mathrm{X} 1$ & 0.040 & -6.155 & Yes & 0.021 & -0.227 \\
\hline & & $\mathrm{C}$ & 0.010 & -2.967 & Yes & 0.053 & 0.838 \\
\hline & & $\mathrm{S}$ & 0.050 & -7.536 & Yes & 0.051 & -0.284 \\
\hline
\end{tabular}


Table 13. Verification and validation parameters definition.

\begin{tabular}{ll}
\hline Parameter & \multicolumn{1}{c}{ Definition } \\
\hline$F$ & $\begin{array}{l}\text { Distribution critical value with respect to the degrees of freedom related to numbers of buildings } \\
\text { and variables }\end{array}$ \\
$t$ & Distribution critical value with respect to the degrees of freedom related to number of buildings \\
$P$-value & The level of significance regarding the confidence level of $95 \%$ \\
$R^{2}$ & Coefficient of determination \\
$R_{\text {Adjusted }}^{2}$ & Adjusted coefficient of determination \\
Standard error & A measure of the statistical accuracy of an estimate \\
Beta & A measure of how strongly each predictor variable influences the dependent variable \\
\hline
\end{tabular}

Table 14. Verification of the proposed models in the first part of the study.

\begin{tabular}{|c|c|c|c|c|c|c|c|c|c|c|c|c|c|c|c|c|c|c|c|c|c|c|}
\hline \multirow[b]{3}{*}{ Ref. } & \multicolumn{8}{|c|}{$\begin{array}{l}\text { Characteristics } \\
\text { of buildings }\end{array}$} & \multicolumn{14}{|c|}{ Characteristics of materials } \\
\hline & \multirow[b]{2}{*}{$\begin{array}{c}\text { FA } \\
\left(\mathrm{m}^{2}\right)\end{array}$} & \multirow[b]{2}{*}{$S$} & \multirow[b]{2}{*}{$X_{1}$} & \multicolumn{7}{|c|}{ Locality } & \multicolumn{3}{|c|}{ Rebar } & \multicolumn{3}{|c|}{ Concrete } & \multicolumn{3}{|c|}{ Brick } & \multicolumn{3}{|c|}{ Cement } \\
\hline & & & & $\boldsymbol{X}_{2}$ & $\boldsymbol{X}_{3}$ & $\boldsymbol{X}_{4}$ & $\boldsymbol{X}_{5}$ & $\boldsymbol{X}_{6}$ & $\boldsymbol{X}_{7}$ & $\boldsymbol{X}_{8}$ & $Y_{\text {Model_1 }}$ & $Y_{\text {Site }}$ & $\begin{array}{c}\left|\boldsymbol{R}_{E}\right| \\
(\%)\end{array}$ & $\boldsymbol{Y}_{\text {Model_1 }}$ & $Y_{\text {Site }}$ & $\begin{array}{c}\left|\boldsymbol{R}_{E}\right| \\
(\%)\end{array}$ & $Y_{\text {Model_1 }}$ & $Y_{\text {Site }}$ & $\begin{array}{c}\left|\boldsymbol{R}_{E}\right| \\
(\%) \\
\end{array}$ & $Y_{\text {Model_1 }}$ & $Y_{\text {Site }}$ & $\begin{array}{c}\left|\boldsymbol{R}_{E}\right| \\
(\%)\end{array}$ \\
\hline 1 & 100 & 7 & 1 & 1 & 0 & 0 & 0 & 0 & 0 & 0 & 1.098 & 1.440 & 23.750 & 2.909 & 4.070 & 28.526 & 6.407 & 8.430 & 23.998 & 1.232 & 1.750 & 29.600 \\
\hline 2 & 210 & 6 & م & 0 & 1 & 0 & 0 & 0 & م & 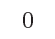 & 1.755 & 2.450 & 28.367 & 3.376 & 4.810 & 29.817 & 7.923 & 10.750 & 26.298 & 16.341 & 12.600 & 29.694 \\
\hline 3 & 136 & 5 & 1 & 0 & 0 & 1 & 0 & 0 & 0 & 0 & & 1.355 & 28.192 & & & 28.438 & & 4.930 & 28.337 & 10.259 & 8.450 & 21.404 \\
\hline 4 & 90 & 5 & 0 & 0 & 0 & 0 & 1 & 0 & 0 & 0 & 1.352 & 1.480 & 8.649 & 4.113 & 5.810 & 29.205 & & 5.250 & 2.095 & 6.207 & 8.390 & 26.024 \\
\hline 5 & 154 & 5 & 0 & 0 & 0 & 0 & 0 & 1 & 0 & 0 & 1.389 & 1.960 & 29.133 & 8.127 & 10.930 & 25.646 & & 6.100 & 29.885 & 4.290 & 6.090 & 29.557 \\
\hline 6 & 82 & 4 & 1 & 0 & 0 & 0 & 0 & 0 & 1 & 0 & 1.302 & 1.170 & 11.282 & 3.143 & 4.159 & 24.420 & 10.187 & 8.690 & 17.227 & 7.858 & 10.500 & 25.165 \\
\hline 7 & 144 & 5 & 0 & 0 & 0 & 0 & 0 & 0 & 0 & 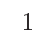 & 1.161 & 0.940 & 23.511 & 4.235 & 6.050 & 29.998 & 16.400 & 19.520 & 15.984 & 9.847 & 11.800 & 16.555 \\
\hline 8 & 120 & 4 & 1 & 1 & 0 & 0 & 0 & 0 & 0 & 0 & 1.302 & 1.544 & 15.674 & 2.649 & 2.488 & 6.455 & 6.407 & 7.256 & 11.701 & 8.542 & 9.521 & 10.285 \\
\hline 9 & 125 & 7 & 0 & 0 & 1 & 0 & 0 & 0 & 0 & 0 & 687 & 2.202 & 23.388 & 4.483 & & 29.627 & & 8.596 & 7.829 & .659 & & 25.078 \\
\hline 10 & 220 & 5 & 1 & 0 & 0 & 1 & 0 & 0 & 0 & 0 & & & & & & & & & & & & \\
\hline 11 & 180 & 6 & 1 & 0 & 0 & 0 & 1 & 0 & 0 & 0 & 0.695 & 0.901 & 22.863 & & 0.897 & & & 4.587 & 20.994 & 9.391 & 10.364 & 9.386 \\
\hline 12 & 195 & 5 & 0 & 0 & 0 & 0 & 0 & 1 & 0 & 0 & 1.389 & 1.899 & 26.856 & 7.593 & 10.358 & 26.693 & 7.923 & 8.654 & 8.447 & 7.559 & 8.654 & 12.650 \\
\hline 13 & 225 & 5 & 0 & 0 & 0 & 0 & 0 & 0 & 1 & 0 & 1.823 & 2.252 & 19.050 & 3.181 & 3.587 & 11.333 & 11.703 & 12.365 & 5.354 & 19.443 & 20.326 & 4.347 \\
\hline 14 & 230 & 5 & 0 & 0 & 0 & 0 & 0 & 0 & 0 & 1 & & 1.487 & 21.923 & & & & & & & & & 1.884 \\
\hline 15 & & 5 & 0 & 1 & 0 & 0 & 0 & 0 & 0 & 0 & & 2.310 & 21.0 & & & & & 8.951 & & & & \\
\hline 16 & 150 & 6 & 1 & 0 & 1 & 0 & 0 & 0 & 0 & 0 & 100 & 1.250 & 6.720 & & & 29.984 & & 7.125 & 10.082 & & 10.365 & 8.635 \\
\hline 17 & & 6 & 0 & 0 & 0 & 1 & 0 & 0 & 0 & 0 & 1.494 & 1.212 & 23.267 & & & 13.670 & & 4.025 & 25.441 & 12.753 & 12.369 & 3.105 \\
\hline 18 & 188 & 7 & 1 & 0 & 0 & 0 & 1 & 0 & 0 & 0 & 0.627 & 0.554 & 13.177 & 0.938 & 1.298 & 27.716 & 3.624 & 4.451 & 18.580 & 8.124 & 10.369 & 21.650 \\
\hline 19 & & 6 & 0 & 0 & 0 & 0 & 0 & 1 & 0 & 0 & & 1.233 & 7.137 & & & 20.532 & & & & & & \\
\hline 20 & 190 & 6 & 1 & 0 & 0 & 0 & 0 & 0 & 1 & 0 & & 1.251 & 6.795 & & & & & & & & 355 & 5.207 \\
\hline 21 & 195 & 6 & 1 & 0 & 0 & 0 & 0 & 0 & 0 & 1 & & 0.670 & 24.776 & & & & & 16.458 & 9.564 & 21 & 10.663 & 6.956 \\
\hline 22 & 175 & 4 & 1 & 1 & 0 & 0 & 0 & 0 & 0 & 0 & & & 18.062 & & & & & & 11.187 & 12.928 & & 24.723 \\
\hline 23 & & 5 & 0 & 0 & 1 & 0 & 0 & 0 & 0 & 0 & 1.823 & 1.534 & 18.840 & & & & 7.923 & 8.657 & 8.479 & 11.867 & & 4.034 \\
\hline 24 & 120 & 5 & 1 & 0 & 0 & 1 & 0 & 0 & 0 & 0 & & 0.889 & 9.449 & & & & & 4.658 & 24.152 & 8.983 & 10.789 & 16.741 \\
\hline 25 & 190 & 6 & 0 & 0 & 0 & 0 & 1 & 0 & 0 & 0 & & 462 & 12.175 & & & 5.407 & & 6.589 & 21.991 & 12.276 & 13.652 & 10.082 \\
\hline 26 & 220 & 7 & 1 & 0 & 0 & 0 & 0 & 1 & 0 & 0 & 364 & 0.895 & 25.810 & & & 12.663 & & 8.547 & 25.038 & 3.656 & 4.895 & 25.316 \\
\hline 27 & 215 & 5 & 0 & 0 & 0 & 0 & 0 & 0 & 1 & 0 & & 2.314 & 21.219 & & & & & & 5.354 & 18.645 & 17.214 & 8.314 \\
\hline 28 & 218 & 6 & 0 & 0 & 0 & 0 & 0 & 0 & 0 & 1 & 1.093 & 1.236 & 11.570 & 3.272 & 4.154 & 21.241 & 16.400 & 19.256 & 14.832 & 13.842 & 12.365 & 11.948 \\
\hline 29 & 170 & 7 & 1 & 1 & 0 & 0 & 0 & 0 & 0 & 0 & 1.098 & 1.254 & 12.440 & 1.998 & 1.769 & 12.923 & 6.407 & 9.125 & 29.786 & 6.814 & 7.156 & 4.782 \\
\hline 30 & 168 & 4 & 1 & 0 & 1 & 0 & 0 & 0 & 0 & 0 & 1.302 & 1.574 & 17.281 & 2.024 & 2.547 & 20.548 & 6.407 & 5.698 & 12.443 & 14.715 & 15.247 & 3.487 \\
\hline 31 & 200 & 5 & 1 & 0 & 0 & 1 & 0 & 0 & 0 & 0 & & 1.250 & 22.160 & & & 19.124 & & 4.365 & 19.061 & 15.362 & 16.452 & 6.625 \\
\hline 32 & 210 & 4 & 0 & 0 & 0 & 0 & 1 & 0 & 0 & 0 & 1.420 & 1.646 & 13.730 & 2.551 & 3.541 & 27.964 & 5.140 & 5.324 & 3.456 & 17.680 & 18.696 & 5.432 \\
\hline
\end{tabular}

part of the study and the proposed reward program, a residential building project client (who was builder of his own projects too and is called builder in the rest of the paper) from private sector was contacted. The authors described the expected benefits of the proposed plan, namely reduction in purchased and wasted materials, environmental pollutions, and landfilled wastes, to persuade him to implement the FI based program during several consecutive meetings. Finally, he gave consent to implementing the plan in a current five-story 
residential building project with an $\mathrm{FA}$ of $285 \mathrm{~m}^{2}$ in Tehran. This study lasted for 4 months. As a result of this reward program, the wasted and purchased amounts of cement were reduced. In this building, concrete was traditionally prepared in site rather than being bought from batching plants. To clarify:

$$
\begin{aligned}
& \Delta P c=P_{2, c}-P_{1, c}, \\
& \Delta W c=W_{2, c}-W_{1, c},
\end{aligned}
$$

where $P_{2, c}$ (or $W_{2, c}$ ) and $P_{1, c}$ (or $W_{1, c}$ ) are amounts of purchased (or wasted) cement after implementing FI program and before it, respectively. Amounts of $P_{2, c}$ and $W_{2, c}$ are calculated after finishing of the case study. Amounts of $P_{1, c}$ and $W_{1, c}$ are estimated according to the experience and judgment of the builder. The total benefit gained would be calculated according to Eq. (34):

Total benefit gained $=-(\Delta W c+\Delta P c) \times$ Price $_{c}$,

where Price $_{c}$ is unit cost of cement. According to Table 15, the benefit gained is $\$ 472.234$. Based on Eqs. (28)-(30):

$$
\begin{aligned}
C W R= & \% C W_{1}-\% C W_{2}=100 \times\left(\frac{W_{1, c}}{P_{1, c}}-\frac{W_{2, c}}{P_{2, c}}\right) \\
= & \frac{810.7}{121000.0}-\frac{310.5}{108500.0}=0.67 \%-0.28 \% \\
= & 0.39 \%, \\
C W R= & 0.39 \%<1.055 \% \rightarrow T F I=0.036 \times C W R \\
& \times F A \times S=0.036 \times 0.39 \times 285 \times 5 \\
= & \$ 20.01 .
\end{aligned}
$$

Based on the estimation of the builder, in his projects, usually $10 \%$ and $6.7 \%$ cement is wasted because of excessive purchase order and lack of supervision during construction, respectively. Therefore, according to Table 15, he ordered 108.5 tons of cement instead of his primary estimation of 121 tons (reducing excessive purchase order policy), because he was determined to reduce cement waste. Furthermore, at the beginning of the project, he assigned the task of reducing cement waste to the possible extent to one of the labor; also, we persuaded him by paying him a reward commensurate with cost savings at the end of the project (reducing avoidable waste policy). The labor avoided the wastage of cement by preventing other labor from discarding semi-filled cement packs and providing better storing conditions. As a result, $301.5 \mathrm{~kg}$ cement was wasted instead of the expected amount of $6.7 \% \times 121$ or $810.7 \mathrm{~kg}$. Finally, the builder saved $\$ 472.234$ and paid the labor $\$ 20.01$ (see Eq. (36)), meaning that reducing avoidable cement waste per se saved a net value of $\$ 452.224$. Considering $\$ 29429$ as the total cost of purchased materials, $\$ 452.224$ reduction in cost of wasted cement accounts for $1.54 \%$ reduction in cost of purchased materials.

\section{Results}

The following results are derived from the first part of the study:

- Cement with average wastage of $8.57 \%$ by weight is the most wasted bulk material. Waste percentages for rebar, concrete, and brick are $1.32 \%, 3.96 \%$, and $7.15 \%$, respectively (Table 9 );

- Locality and contract type variables are modeled in quantitative forms, concurrently;

- Building materials waste can be quantified rather than the total wasted materials to contrive plans for reduction in each building material waste;

- Effects of all studied variables on BMW are determined as follows:

- In a specific model, the difference between two locality coefficients shows how much the wastage of the same material will be changed if a particular building is constructed in the second location instead of the first location;

- The coefficient $X_{1}$ is negative in all models. Thus, materials are more waste-prone in projects with cost-plus contract than in those with lump-sum contracts. Considering the values of coefficient $X_{1}$ in the developed models, it is concluded that choosing cost-plus contract instead of lumpsum contract increases wastage by up to $0.589 \%$, $1.899 \%, 1.516 \%$, and $2.087 \%$ for rebar, concrete, brick, and cement, respectively (Figure 2). By dividing these values into corresponding average waste percentages from Table 9, 44.62\%, 47.96\%, $21.20 \%$, and $24.35 \%$ relative waste increases for rebar, concrete, brick, and cement are resulted. This is an auspicious result, because cost-plus contract rules and regulations lead to contractor apathy toward heedful use of materials, which is opposed to CW reduction. Therefore, cost-plus contract, which is common in Iran for traditional

Table 15. Conducted case study results.

\begin{tabular}{cccccccc}
\hline Material & Unit & Price $_{\boldsymbol{c}}(\$)$ & $\boldsymbol{P}_{\mathbf{1}, \mathbf{c}}$ & $\boldsymbol{P}_{\mathbf{2}, \boldsymbol{c}}$ & $\boldsymbol{W}_{\mathbf{1}}, \boldsymbol{c}$ & $\boldsymbol{W}_{\mathbf{2}, \boldsymbol{c}}$ & Benefit (\$) \\
\hline Cement & $\mathrm{kg}$ & 0.0363 & 121000.00 & 108500.00 & 810.7 & 301.5 & 472.234 \\
\hline
\end{tabular}


residential buildings, is considered an improper contract type according to $\mathrm{CW}$ management policies.

- MLR is proved to be a pertinent tool to CWG quantification;

- Interpreting the values of independent variable $S$ :

- Rebar is mostly wasted due to uneconomical overlaps and cut-offs, which are intensified when more rebar is required. Forces and moments decrease in upper stories when less rebar is required. Therefore, the more the number of stories, the less the required rebar, overlaps, cut-offs, and waste will be. This makes the coefficient $S$ in rebar waste model negative;

- Cement is wasted due to poor transportation and storage conditions as well as discarding semi-filled sacks manually by the labor, which happens more in lower stories than in upper ones where cement sacks are lifted electro-mechanically. Hence, cement waste percent decreases as the number of stories increases. This makes the coefficient $S$ in cement waste model negative;

- Brick is wasted mostly during transportation. Bricks usually are lifted to upper stories by electro-mechanical lift, which is not supposed to damage bricks. Therefore, the number of stories has relatively no effect on brick waste;

- Concrete is wasted by remaining in pumping tubes, which is not used elsewhere. The volume of tube is constant, meaning that the maximum amount of wasted concrete is limited to this volume. Therefore, the number of stories has relatively no effect of concrete waste.

- Interpreting the values of independent variable $A$ :

- As mentioned in the previous interpretation, the main culprit of brick waste is transportation. In construction sites, brick is lifted to stories and then carried by the labor. Brick wastage during this carriage is negligible in comparison with that during transportation. Thus, floor area does not affect brick waste;

- Rebar is produced in 12-meter elements in Iran. Lengths of the beams are usually more than $12 \mathrm{~m}$; therefore, less cut-offs and overlaps are required than columns, which are about $3 \mathrm{~m}$. Thus, floor area does not affect rebar waste;

- The more the floor area, the more concrete is required, while the wasted concrete volume cannot be more than the pumping tube volume. Therefore, weight percent of concrete waste decreases as the floor area increases and the coefficient $A$ in concrete waste model is negative;

- Cement on stories can be wasted due to reckless pulling of cement sacks on harsh ground by the labor, which hurts the sacks and results in cement waste. The bigger the plan area, the more the pulling distance and the cement waste are. Therefore, coefficient $A$ in cement waste model is positive.

- For rebar, concrete, brick, and cement, adjusted coefficients of determination $\left(R_{\text {Adjusted }}^{2}\right)$ equal 0.907 , $0.790,0.920$, and 0.875 , respectively, meaning that the studied variables approximately measure $90.70 \%, 79.00 \%, 92.00 \%$, and $87.50 \%$ the factors involved in the BMs wastage.

The following are the results of the second part of the study, which lead to cement waste reduction:

- In Eq. (13), the values of coefficients $A$ and $S$ are +7.974 and -1.905 , respectively, meaning that smaller buildings with more stories surpass bigger buildings with fewer stories in reducing cement wastage. This can be regarded by the municipality of Tehran in developing new public housing projects as well as residential building projects in northern Tehran in future, e.g., the studied location, i.e., Saadat-Abad, where construction of large one- or two-story buildings is commonplace;

- Elasticity concept along with MLR can be used in cement waste management;

- Reward based programs are preferred and proposed by construction industry experts to contrive BMW adeptly;

- The proposed FI works well in curtailing cement waste;

- The proposed FI program is justifiable both economically and environmentally. Table 16 summarizes the environmental and economic evaluations of this FI and its advantages;

- About $90 \%$ of permits for residential buildings are issued for 4- to 7-story buildings in Tehran [36]. This is why the authors chose these kinds of buildings. The locations were selected in a manner that covered nearly all locations of Tehran. In other words, design and construction methods of buildings in other locations were similar to those of the studied buildings. Hence, the chosen buildings were studied in such a manner that represented the majority of residential buildings in Tehran. This means that the proposed FI is applicable to approximately all residential buildings in Tehran with an acceptable error level;

- $P$-values for all derived models in Eqs. (10) to (13) and (16) to (19) are less than 0.05; all the same, the standard errors of some coefficients exceed 0.05 . It means that the studied independent variables all together have a good correlation with the dependent 
Table 16. Summarizing the proposed FI implementation advantages (per 1\% FI increase).

\begin{tabular}{|c|c|c|c|c|c|c|c|c|c|}
\hline \multicolumn{4}{|c|}{ Economic viability elements } & \multicolumn{5}{|c|}{ Environmental justifiability } & \multirow{3}{*}{$\begin{array}{l}\text { Reduction in air } \\
\text { pollutants emission } \\
\quad \text { (ton per year) }\end{array}$} \\
\hline \multirow[t]{2}{*}{$\begin{array}{c}C_{1} \\
\left(\$ / \mathbf{m}^{2}\right)\end{array}$} & \multirow[t]{2}{*}{$\begin{array}{c}B_{1} \\
\left(\$ / \mathbf{m}^{2}\right)\end{array}$} & \multirow[t]{2}{*}{$\begin{array}{c}\Delta C \\
\left(\$ / \mathbf{m}^{2}\right)\end{array}$} & \multirow[t]{2}{*}{$\begin{array}{c}\Delta B \\
\left(\$ / \mathbf{m}^{2}\right)\end{array}$} & \multicolumn{2}{|c|}{$\begin{array}{l}\text { Cement waste } \\
\text { reduction }\end{array}$} & \multicolumn{3}{|c|}{$\begin{array}{c}\text { Reduction } \\
\text { in resources } \\
\text { consumption }\end{array}$} & \\
\hline & & & & $\begin{array}{c}\text { Relative } \\
(\%)\end{array}$ & $\begin{array}{l}\text { Total } \\
\text { (ton per } \\
\text { year) }\end{array}$ & $\begin{array}{c}\text { Raw } \\
\text { materials } \\
\text { (ton per } \\
\text { year) }\end{array}$ & $\begin{array}{c}\text { Electrical } \\
\text { energy } \\
\text { (million } \\
\text { kWh per } \\
\text { year) }\end{array}$ & $\begin{array}{c}\text { Heat } \\
\text { energy } \\
\text { (billion kcal } \\
\text { per year) }\end{array}$ & \\
\hline 0.745 & 0.720 & 0.020 & 0.057 & 1.56 & 7332 & 12024.48 & 0.732 & 6.065 & 11425.236 \\
\hline
\end{tabular}

variable, but a single independent variable does not necessarily correlate with the corresponding dependent variable. In other words, wastage of a specific studied material is a function of a set of independent variables rather than a sole independent variable. This result is very close to the result for a current MLR conducted by Kern et al., 2015 [9];

- Linear property makes the models less timeconsuming to analyze. This advantage accelerated designing, evaluating, and finalizing the financial incentive-based proposal in the second part of the research;

- There is theoretical relationship between FI and CWR in the residential building projects of Tehran;

- Part of cost savings due to reducing avoidable wastes and excessive purchased materials can be used to persuade the labor into reducing wasted materials to the possible extent;

- According to the results for the case study, the proposed FI program reduced cement waste from $0.67 \%$ to $0.28 \%$, which equaled $0.39 \%$ CWR (Eq. (35));

- Saving of implementing the proposed financial reward system is $\$ 452.224$ and regarding $\$ 29429$ as the total cost of purchased materials, this saving in cost of wasted cement accounts for $1.54 \%$ reduction in cost of purchased materials.

\section{Conclusions}

The authors used trial-and-error method to select a regression method for quantification. In trial-and-error method, the first trial can be the simplest and most available one [44] and if this trial does not lead to satisfactory results, the process has to be repeated with another trial. After that Kern et al. (2015) in a recent research used MLR to quantify waste generation in Brazil, the authors were persuaded to choose MLR as the first trial. After applying this method, the results would be analyzed. In this study, fortunately, MLR as the first trial led to suitable results. In other words, the adjusted coefficients of determination $\left(R_{\text {Adjusted }}^{2}\right)$ for the developed models were in the acceptable range in the review of the literature $[9,36]$. As a result, no other regression method was tested to quantify wastages.

Regarding research limitations, in the first part of the study, models were developed to engender a good database for BMW in residential building projects of Tehran by determining quantitative effects of different variables, e.g., contract type. The result was in a good agreement with the reviewed literature and contractual origin of CWG was identified as a rudimentary one directly influencing other origins (purchase, storage, on-site carriage, etc.) [2].

The second part of the study focused on finding solutions to reducing cement as the most wasted material. Selecting a proper contract type would prevent wasteful utilization of cement. Considering regulations of the studied contracts from the CW management viewpoint, lump-sum contract was suggested instead of cost-plus contract generally made in traditional residential buildings construction in Tehran. Furthermore, the suggested FI, of which viability and environmental friendliness were confirmed, was a proper managerial tool to persuade contractors into reducing cement wastage.

The results of this paper are a testimony to the fact that CWG quantification alleviates devising unique solutions to BMW, i.e., reducing cement waste, recycling rebar and concrete, reusing brick, etc., which is incumbent upon urban managers. In this study, an FI program reduced the quantity of wasted cement in residential buildings, but did not eliminated it completely. It is suggested that future researchers work on methods of zero waste buildings, which previously targeted zero-killed and zero-accident construction projects. In addition, it may be asserted that although the studied case was residential buildings of Tehran, it is possible to generalize and apply the model to other locations. To do this, the following modifications have to be made:

1. Determining the major contract types of the new location;

2. Selecting a state and dividing it to smaller locations in the study; 
3. Developing a new financial incentive based scheme compatible with local regulations; and

4. Identifying the major construction materials of the new location.

In summary, contributions of this paper, compared to previous similar studies, include:

- Proposing quantification as an apt tool for CW management and planning;

- Introducing MLR as a suitable mathematical tool of CW quantification;

- Simultaneous inclusion of contract type and locality as qualitative factors;

- Suggesting financial incentive as a new method for cement waste management;

- Quantifying the influence of financial incentive on cement waste; and

- Identifying environmental evaluation as an important factor in designing financial incentive based plans besides the previously proposed criterion (economic parameter [24,45-48]).

Finally, the following are the research limitations, which might be addressed in the future academic studies:

- Concentration on residential buildings with concrete structure, which have a great share among construction projects in Tehran;

- Disregarding the effects of parameters like skill, training, and education level of the labor; and

- Concentration on four BMs only.

The future scholars may use other quantification methods such as binomial regression, polynomial regression, etc. and compare their results with those of the present paper.

\section{Acknowledgement}

Authors are grateful to all experts participating in the field observations and surveys for providing data and information.

\section{Acronyms}

$\begin{array}{ll}\text { BM } & \text { Building Material } \\ \text { BMW } & \text { Building Material(s) Waste } \\ \text { C\&DW } & \text { Construction and Demolition Waste } \\ \text { CW } & \text { Construction Waste } \\ \text { CWG } & \text { Construction Waste Generation } \\ \text { CWR } & \text { Cement Waste Reduction } \\ \text { FA } & \text { Floor Area } \\ \text { FI } & \text { Financial Incentive } \\ \text { MLR } & \text { Multiple Linear Regression }\end{array}$

\section{References}

1. Yano, J. and Sakai, S. "Waste prevention indicators and their implications from a life cycle perspective: a review", J Mater Cycles Waste Manag, 18, pp. 38-56 (2016).

2. Mortaheb, M.M. and Mahpour, A. "Integrated construction waste management a holistic approach", Scientia Iranica, 23, pp. 2044-2056 (2016a).

3. Wu, H., Duan, H., Wang, J., Wang, T., and Wang, $\mathrm{X}$. "Quantification of carbon emission of construction waste by using streamlined LCA: a case study of Shenzhen, China", J Mater Cycles Waste Manag, 17, pp. 637-645 (2015).

4. Taghipour, H., Amjad, Z., Aslani, H., Armanfar, F., and Dehghanzadeh, R. "Characterizing and quantifying solid waste of rural communities", J Mater Cycles Waste Manag (Regional Case Study), 18(4), pp. 1-8 (2015).

5. Memon, M.A. "Integrated solid waste management based on the 3R approach", J Mater Cycles Waste Manag, 12, pp. 30-40 (2010).

6. Aljassar, A.H., Al-Fadala, K.B., and Ali, M.A. "Recycling building demolition waste in hot-mix asphalt concrete: a case study in Kuwait", J Mater Cycles Waste Manag, 7, pp. 112-115 (2005).

7. Chou, J.S. and Yeh, K.C. "Life cycle carbon dioxide emissions simulation and environmental cost analysis for building construction", J Clean Prod, 101, pp. 137147 (2015).

8. Marzouk, M. and Azab, S. "Environmental and economic impact assessment of construction and demolition waste disposal using system dynamics", Resour Conserv Recy, 82, pp. 41-49 (2014).

9. Kern, A.P., Dias, M.F., Kulakowski, M.P., and Gomes, L.P. "Waste generated in high-rise buildings construction: A quantification model based on statistical multiple regression", Waste Manage, 39, pp. 35-44 (2015).

10. Wu, Z., Yu, A.T.W., Shen, L., and Liu, G. "Quantifying construction and demolition waste: An analytical review", Waste Manage, 34, pp. 1683-1692 (2014).

11. Mortaheb, M.M. and Mahpour, A. "Quantification of construction waste production of bulk materials (case study: Residential buildings in Tehran)", Accepted for Publication in Sharif Journal of Science \& Technology (2016b) (In Persian).

12. Coelho, A. and Brito, J.D. "Influence of construction and demolition waste management on the environmental impact of buildings", Waste Manage, 32, pp. 532541 (2012).

13. Jang, H. and So, S. "The properties of cement-based mortar using different particle size of grinding waste insulator powder", J Build Eng, 3, pp. 48-57 (2015).

14. Sáez, P.V., Porras-Amores, C., and Merino, M.D.R. "New quantification proposal for construction waste generation in new residential constructions", J Clean Prod, 102, pp. 58-65 (2015). 
15. Ding, T. and Xiao, J. "Estimation of buildingrelated construction and demolition waste in Shanghai", Waste Manage, 34, pp. 2327-2334 (2014).

16. Li, J., Ding, Z., Mi, X., and Wang, J. "A model for estimating construction waste generation index for building project in China", Resour Conserv Recy, 74, pp. 20-26 (2013).

17. Won, J., Cheng, P.C.B., and Lee, G. "Quantification of construction waste prevented by BIM-based design validation: Case studies in South Korea", Waste Manage, 49, pp. 170-180 (2016).

18. Ghosh, S.K., Haldar, H.S., Chatterjee, S., and Ghosh, P. "An optimization model on construction and demolition waste quantification from building", Procedia Environmental Sciences, 35, pp. 279-288 (2016).

19. Hotta, Y., Visvanathan, C., Visvanathan, M., and Pariatamby, A. "Developing 3R policy indicators for Asia and the pacific region: experience from regional 3R forum in Asia and the pacific", J Mater Cycles Waste Manag, 18, pp. 22-32 (2016).

20. Office of Organizing Urban Services, Regulation of Organizing Construction and Demolition Waste, Ministry of Interior, Tehran (2012) (In Persian).

21. Oh, D., Noguchi, T., Kitagaki, R., and Park, W. " $\mathrm{CO}_{2}$ emission reduction by reuse of building material waste in the Japanese cement industry", Renew Sust Energ Rev, 38, pp. 796-810 (2014).

22. Ostad-Ahmad-Ghorabi, M.J. and Attari, M. "Advancing environmental evaluation in cement industry in Iran", J Clean Prod, 41, pp. 23-30 (2013).

23. Zeng, L., Zhu, H., Ma, Y., Huang, J., and Li, G. "Greenhouse gases emissions from solid waste: an analysis of Expo 2010 Shanghai, China", J Mater Cycles Waste Manag, 16, pp. 616-622 (2014).

24. Tam, V.W.Y. and Tam, C.M. "Waste reduction through incentives: a case study", Build Res Inf, 36, pp. 37-43 (2008).

25. Chen, Z., Li, H., and Wong, T.C.C. "An application of bar-code system for reducing construction wastes", Automat Constr, 11, pp. 521-533 (2002).

26. Kanafani, A., Transportation Demand Analysis, McGraw-Hill, California, USA (1983).

27. Boser, R.A. and El-Gafy, M. "Accelerating waste minimization in residential construction: A source separation case study", Int J Construct Educ Res, 7, pp. 58-70 (2011).

28. Lippman, S.A., McCardle, K.F., and Tang, C.S. "Using Nash bargaining to design project management contracts under cost uncertainty", Int J Prod Econ, 145, pp. 199-207 (2013).
29. Udawatta, N., Zuo, J., Chiveralls, K., and Zillante, G. "Improving waste management in construction projects: An Australian study", Resour Conserv Recy, 101, pp. 73-83 (2015).

30. Hang, J., Li, Y., Sandberg, M., Buccolieri, R., and Sabatino, S.D. "The influence of building height variability on pollutant dispersion and pedestrian ventilation in idealized high-rise urban areas", Build Environ, 56, pp. 346-360 (2012).

31. Chen, W., Hong, J., and Xu, C. "Pollutants generated by cement production in China, their impacts, and the potential for environmental improvement", J Clean Prod, 103, pp. 61-69 (2014).

32. Begum, R.A., Siwar, C., Pereira, J.J., and Jaafar, A.H. "Attitude and behavioral factors in waste management in the construction industry of Malaysia", Resour Conserv Recy, 53, pp. 321-328 (2009).

33. Municipality of Tehran, Charging Code for Tehran, General Government of Tehran, Tehran (2015) (In Persian).

34. Iranian National Tax Administration (INTA), Tehran Buildings Trading Value Code, Ministry of economic affairs and finance, Tehran (2014) (In Persian).

35. Banks, J., Carson, J., Nelson, B.L., and Nicol, D., Discrete-Event System Simulation, Prentice Hall, New Jersey, USA (2005).

36. Walpole, R.E., Myers, R.H., and Myers, S.L., Probability and Statistics for Engineers and Scientists, Prentice Hall, New Jersey, USA (1998)

37. Landau, S. and Everitt, B.S., A Handbook of Statistical Analyses Using SPSS, CRC, Florida, USA (2004).

38. Cochran, K., Townsend, T., Reinhart, D., and Heck, $\mathrm{H}$. "Estimation of regional building-related C\&D debris generation and composition: case study for Florida, US", Waste Manage, 27, pp. 921-931 (2007).

39. Chi, Y., Dong, J., Tang, Y., Huang, Q., and Ni, M. "Life cycle assessment of municipal solid waste sourceseparated collection and integrated waste management systems in Hangzhou, China", J Mater Cycles Waste Manag, 17, pp. 695-706 (2015).

40. Mahpour, A., Mortaheb, M.M., and Sebt, M.H. "Evaluating the effect of financial incentive on construction waste generation in Tehran's residential buildings", Proceedings of the 11th International Project Management Conference, Tehran, Iran (Feb. 2016) (In Persian).

41. Statistical Center of Iran, Issued Construction Permits, Management and Planning Organization of Iran, Tehran (2016) (In Persian).

42. Statistical Center of Iran, Building Materials' Prices, Management and planning organization of Iran, Tehran (2016) (In Persian). 
43. Barker, D.J., Turner S.A., Napier-Moore, P.A., Clark, M., and Davison, J.E. " $\mathrm{CO}_{2}$ capture in the cement industry", Energy Procedia, 1, pp. 87-94 (2009).

44. Ye, H., Yang, H., and Tan, Z. "Learning marginalcost pricing via trial-and-error procedure with day-today flow dynamics", 21st International Symposium on Transportation and Traffic Theory, ISTTT21, Kobe, Japan (Aug. 2015).

45. Mahpour, A. and Mortaheb, M.M. "Financial-based incentive plan to reduce construction waste", J Constr Eng Manag, 144(5) (2018).

https://doi.org/10.1061/(ASCE)CO.19437862.0001461

46. Mahpour, A., Mortaheb, M.M., and Sebt, M.H. "Cement waste reduction framework in Tehran's concrete structure residential buildings", Sharif Journal of Science and Technology, 34.2(3.2), pp. 93-104 (2018) (In Persian).

47. Mahpour, A. and Mortaheb, M.M. "Managing materials' wastage in construction sites based on stakeholders' involvement as well as reducing excessive purchase and avoidable waste", 10th National Congress on Civil Engineering, Tehran, Iran, April (2017) (In Persian).

48. Mahpour, A. "Prioritizing barriers to adopt circular economy in construction and demolition waste management", Resour Conserv Recy, 134, pp. 216-227 (2018).

\section{Biographies}

Amirreza Mahpour received his BSc degree in 2014 from Amirkabir University of Technology, Tehran, Iran, and his MSc degree in Construction Engineering and Management in 2016 from Sharif University of
Technology, Tehran, Iran, with honors during all the 6 years of studies. His research is within the field of construction and demolition waste management and devising policies to manage this kind of solid waste. He started his $\mathrm{PhD}$ program at the University of Toronto in September 2018.

Amin Alvanchi received his $\mathrm{PhD}$ in 2011 in Construction Engineering and Management from the University of Alberta, Canada. He has been working as an Assistant Professor in the Department of Civil Engineering at Sharif University of Technology, Tehran, Iran, since 2013. During his four-year career at Sharif University of Technology, Dr. Alvanchi has supervised more than 10 graduate students and has been involved in several industrial research efforts in different areas of research, including project management, construction operation simulation, contract administration, and sustainability and construction materials.

Mohammad Mehdi Mortaheb received his $\mathrm{PhD}$ in 1990 in Construction Materials and Management from University of Kentucky, Lexington, KY, USA. He has been a member of the scientific committees of several national and international conferences related to project and construction management and supervised many graduate students doing their MSc degrees at Sharif University of Technology (SUT) and other universities. He has been active in directing and managing different real projects, especially in pipe line as well as oil, gas, and petrochemical industries of Iran over the last 42 years. 